\title{
Exploring interacting influences on the silicon isotopic composition of the surface ocean: a case study from the Kerguelen Plateau
}

\author{
N. Coffineau, C. L. De La Rocha, and P. Pondaven \\ Institut Universitaire Européen de la Mer, CNRS UMR6539, Université de Bretagne Occidentale, Plouzané, France
}

Correspondence to: N. Coffineau (nathalie.coffineau@univ-brest.fr)

Received: 28 June 2013 - Published in Biogeosciences Discuss.: 10 July 2013

Revised: 30 November 2013 - Accepted: 21 January 2014 - Published: 12 March 2014

Abstract. This study presents six new water column profiles of the silicon isotopic composition $\left(\delta^{30} \mathrm{Si}\right)$ of dissolved silicon (DSi) from the Atlantic and Indian sectors of the Southern Ocean and a variable depth box model of silica cycling in the mixed layer that was constructed to illuminate the evolution of surface ocean $\delta^{30} \mathrm{Si}$ over the full course of a year. In keeping with previous observations, $\delta^{30} \mathrm{Si}$ values ranged from +1.9 to $+2.4 \%$ in the mixed layer (ML), +1.2 to $+1.7 \%$ in Winter Water (WW), and +0.9 to $+1.4 \%$ in Circumpolar Deep Water (CDW). These data also confirmed the occurrence of diminished values for $\mathrm{ML} \delta^{30} \mathrm{Si}$ at low DSi concentrations in early austral autumn on the Kerguelen Plateau. The box model was used to investigate whether these low, post-growing season values of $\delta^{30} \mathrm{Si}$ were related to input of DSi to the ML from basalt weathering, biogenic silica dissolution (with or without isotopic fractionation), the onset of winter mixing, or some combination of the three. Basalt weathering and fractionation during biogenic silica dissolution could both lower ML $\delta^{30} \mathrm{Si}$ below what would be expected from the extent of biological uptake of DSi. However, the key driver of the early autumn decrease in $\delta^{30} \mathrm{Si}$ appears to be the switch from bloom growth (with net removal of DSi and net accumulation of biogenic silica (BSi) biomass) to steady state growth (when slow but continuing production of BSi prevented significant net increase in DSi concentrations with diffusive input of DSi from WW but not decrease in ML $\delta^{30} \mathrm{Si}$ towards WW values). Model results also indicated that fractionation during dissolution has only a negligible effect on the $\delta^{30} \mathrm{Si}$ of BSi exported throughout the course of the year. However, seasonal changes in export efficiency (e.g. favouring the export of bloom BSi versus the export of BSi produced during other times of the year) should strongly influence the $\delta^{30} \mathrm{Si}$ of $\mathrm{BSi}$ accumulating in marine sediments.
Finally, the choice for the parameterisation of the mixing between the ML and the WW in terms of $\delta^{30} \mathrm{Si}$ (i.e. constant or allowed to vary with the seasonal migration of the thermocline) is critical to take into account in box model simulations of the silica biogeochemical cycle. Altogether, these results suggest that as a paleoceanographic proxy, $\delta^{30} \mathrm{Si}$ may more reflect the dominant mode of production of the BSi that is exported (i.e. bloom versus steady state growth) rather than strictly the extent of DSi utilisation by diatoms.

\section{Introduction}

Diatoms, which are phytoplankton that produce frustules of amorphous, hydrated silica (opal), fractionate silicon isotopes when they take up dissolved silicon (DSi) and use it to produce this biogenic silica (BSi). This results in BSi with a silicon isotopic composition $\left({ }^{30} \mathrm{Si}\right)$ roughly $-1.1 \%$ o lower relative to its DSi source and marine surface waters with $\delta^{30} \mathrm{Si}_{D S i}$ values that generally increase as DSi is increasingly removed by diatoms (De La Rocha et al., 1997, 2000, 2011; Milligan et al., 2004; Varela et al., 2004; Cardinal et al., 2005; Beucher et al., 2008, 2011; Fripiat et al., 2011b; Fripiat et al., 2011c; de Brauwere et al., 2012; de Souza et al., 2012a). A pure relationship between the biological removal and the isotopic composition of DSi is, however, complicated by input of DSi to the surface ocean through vertical mixing (and the episodic versus continuous nature of this input relative to the biological uptake of DSi), the dissolution of BSi (a process which may have an isotopic fractionation of $-0.55 \%$ associated with it; Demarest et al., 2009), and, in relevant regions, the weathering of lithogenic silica such as basalt (Fripiat et al., 2011b, c; Oelkers et al., 2011). 


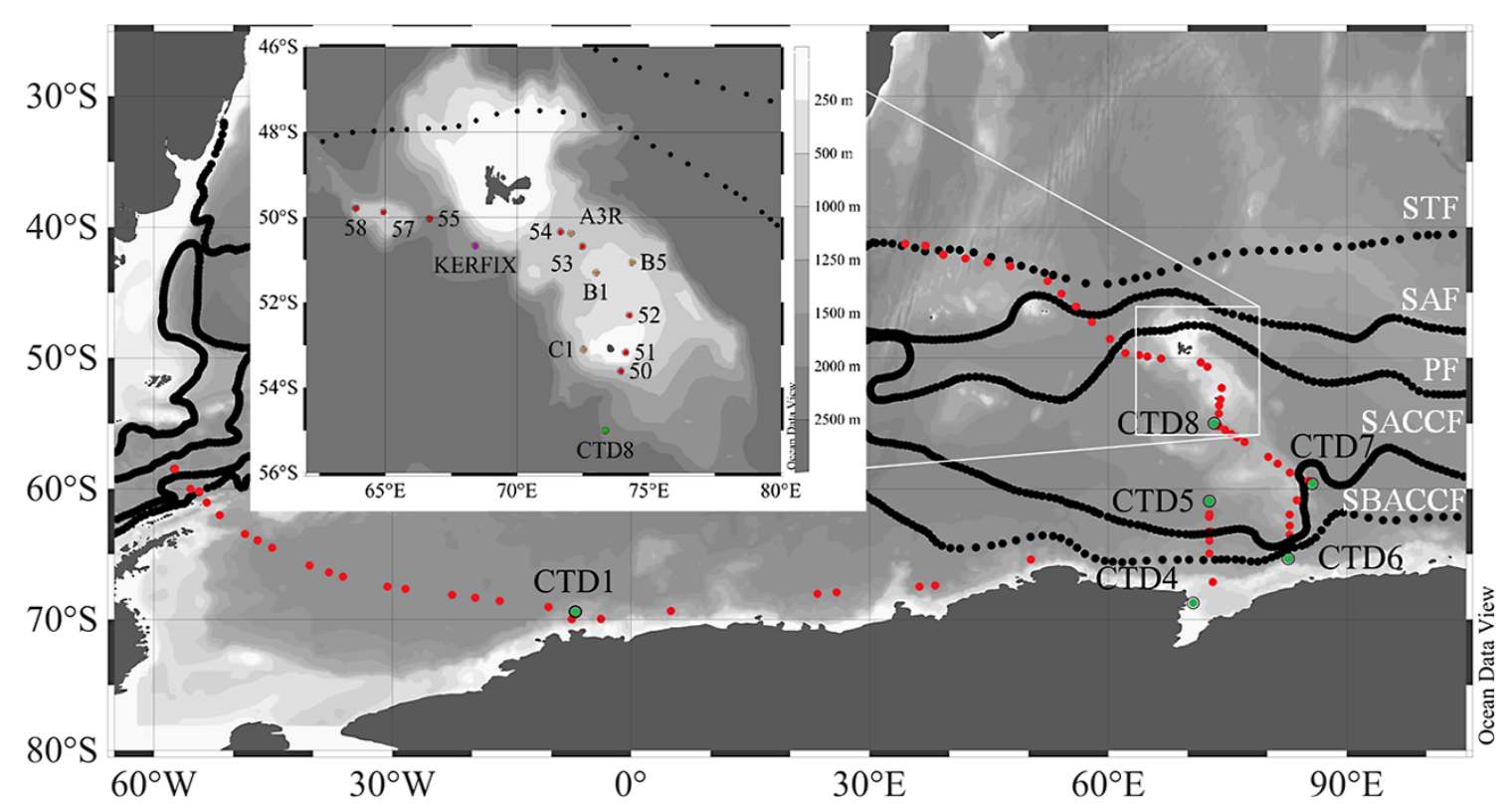

Fig. 1. Map of the study area in the Atlantic and Indian sectors of the Southern Ocean. Red dots are surface water samples from De La Rocha et al. (2011) and green dots represent the CTD stations from this study. The inset shows the area from the north of Kerguelen Island to the south of Heard Island to show the Kerguelen Plateau in more detail. Stations numbered A3R, B1, B5 and C1 are KEOPS stations from Fripiat et al. (2011b), the KERFIX time series site is from Jeandel et al. (1998), stations numbered from 50 to 55 are surface samples from De La Rocha et al. (2011), and CTDs from 1 to 8 are from this study. Black lines represent the Subtropical Front (STF), the Subantarctic Front (SAF), the Polar Front (PF), the Southern Antarctic Circumpolar Current Front (SACCF), and the Southern Boundary of the Antarctic Circumpolar Current Front (SBACCF) of the Antarctic Circumpolar Current.

One of the places where the distribution of silicon isotopes has been most intensely investigated is the Southern Ocean, which, in addition to being one of the major high nutrient, low chlorophyll (HNLC) regions of the ocean, is an ocean with a strong and dynamic silica cycle. Among the Southern Ocean's key features is the Antarctic Circumpolar Current (ACC) that connects the Indian, Atlantic, and Pacific ocean basins (Orsi et al., 1995). This strong circumpolar flow is diverted in places by submarine topography and this is particularly the case for the Kerguelen Plateau (Fig. 1) (Orsi et al., 1995; Cunningham, 2005; Park et al., 2008). The Kerguelen Plateau is a large igneous province (LIP) in the Indian sector of the Southern Ocean that acts as a barrier to the circumpolar flow of the ACC, forcing $2 / 3$ of the flow to pass along the northern escarpment of the plateau, which lies to the north of Kerguelen Island, and the remaining third to flow through the Fawn Trough, which lies to the south of Heard Island (Park et al., 1993; Mongin et al., 2008; Roquet et al., 2009). Thus, despite being in the midst of the ACC, the relatively shallow region between Kerguelen Island and Heard Island represents a zone of weak eastward circulation (Park et al., 1998b; McCartney and Donohue, 2007; Roquet et al., 2009), with the potential for a high degree of nutrient recycling (due to its retention of water and particulates) and of input of material from the subaerial and submarine weathering of basalt. These factors, along with natural iron fertilization on the plateau (Blain et al., 2007), allow considerable biological nutrient removal and buildup of standing stocks of chlorophyll and BSi to occur in this area during phytoplankton blooms relative to the surrounding open ocean waters of the ACC (De La Rocha et al., 2011; Fripiat et al., 2011b).

Interestingly, in this region between Kerguelen Island and Heard Island, the $\delta^{30} \mathrm{Si}$ of DSi in surface waters (depths of $10-50 \mathrm{~m})$ at low concentrations of DSi is high $(+2.4$ to $+2.7 \%$ at 2 to $12 \mu \mathrm{M}$ ) in late January/early February (about six weeks into austral summer) (Fripiat et al., 2011b). This is as expected from a high degree of biological removal of DSi, but by the end of March (early austral autumn) this is no longer the case (De La Rocha et al., 2011). At this point, at concentrations of DSi which are still low (4 to $17 \mu \mathrm{M})$, surface water $\delta^{30} \mathrm{Si}$ clusters around $+1.8 \%$ (De La Rocha et al., 2011), suggesting that some process has lowered surface water $\delta^{30} \mathrm{Si}$ without notably increasing DSi concentrations. This early autumn decrease in $\delta^{30} \mathrm{Si}$ could represent the beginning of seasonal mixing of Winter Water (whose $\delta^{30} \mathrm{Si}$ ranges between +1.2 and $+2.2 \%$ (Fripiat et al., 2011b)) into the surface mixed layer on the plateau. Alternatively, the DSi pool in the mixed layer in early autumn, when DSi concentrations are low, could contain a maximal proportion of DSi from basalt weathering (which could have a $\delta^{30} \mathrm{Si}$ of anywhere from -1.0 to $+1.5 \%$ (Ziegler et al., 2005; Georg et al., 2007b), based on studies of the subaerial weathering of basalt). Lastly, the early autumn DSi pool could also or instead contain a significantly high proportion of DSi that was 
dissolved from sinking $\mathrm{BSi}$, which would also act to lower its $\delta^{30} \mathrm{Si}$.

To examine these possibilities, we constructed a biogeochemical model of silica and silicon isotope cycling in the region. In this model, phytoplankton growth rates are controlled by the availability of light (i.e. depending on day length and mixed layer depth) and DSi concentrations. DSi is input to the mixed layer by deepening of the mixed layer depth and, in some simulations, from basalt weathering. The DSi incorporated into BSi that does not dissolve within the mixed layer is exported from it through sinking. This model differs considerably from the models recently presented by de Brauwere et al. (2012) and Fripiat et al. (2012) by being driven by changes in mixed layer depth and day length and by incorporating basalt as a potential source of DSi. This model can be used to track the size and $\delta^{30} \mathrm{Si}$ of dissolved and biogenic silica pools throughout the year and to follow the $\delta^{30} \mathrm{Si}$ values related to bloom versus steady state phytoplankton growth and silica production, surface ocean stratification versus mixing, and the dissolution of $\mathrm{BSi}$ and/or basalt.

\section{Material and methods}

\subsection{Data sampling and analyses}

During the ANTXXIII/9 campaign that took place in the Southern Ocean in February-April 2007, samples for silicon isotopes $\left(\delta^{30} \mathrm{Si}\right)$ were collected from six depth profiles (Fig. 1) along the edge of the ice shelf in the Atlantic and Indian sectors of the Southern Ocean and on the Kerguelen Plateau (see De La Rocha et al. (2011) for more details of the cruise). Water samples from the Niskin bottle rosette were filtered through $0.6 \mu \mathrm{m}$ polycarbonate filters and then stored at room temperature in acid-cleaned LDPE bottles. The dissolved silicon concentrations of these never-frozen samples were measured colorimetrically with a spectrophotometer (Shimadzu UV-1700) following the formation and reduction of silicomolybdate (Strickland and Parsons, 1972).

The first step in the isotopic analysis of the DSi was its extraction as triethylamine silicomolybdate and then combustion to form $\mathrm{SiO}_{2}$ (De La Rocha et al., 1996). This silica was dissolved in $40 \% \mathrm{HF}$ at an F : Si ratio of $100 \mathrm{~mol} \mathrm{~mol}^{-1}$, ensuring enough of an excess of $\mathrm{F}$ to form $\mathrm{SiF}_{6}^{2-}$ ions rather than $\mathrm{SiF}_{4}$ gas. The silicon was further purified via anion exchange chromatography following Engström et al. (2006), as detailed in De La Rocha et al. (2011). In brief, samples of $4 \mu \mathrm{mol} \mathrm{Si}$ in $52 \mathrm{mM}$ HF were loaded onto columns of AG 1-X8 resin (100-200 mesh, Eichrom) preconditioned with $2 \mathrm{M} \mathrm{NaOH}$. Any contaminants remaining after the initial extraction and combustion were eluted using a solution of $95 \mathrm{mM} \mathrm{HCl}+23 \mathrm{mM}$ HF. Purified Si was then eluted with a solution of $0.14 \mathrm{M} \mathrm{HNO}_{3}+5.6 \mathrm{mM} \mathrm{HF}$. All acids used were Suprapur (Merck) and were diluted using MilliQ water $\left(18.2 \mathrm{M} \Omega \mathrm{cm}^{-1}\right)$.
Purified samples were diluted to $2 \mathrm{ppm} \mathrm{Si}$ and doped with $0.1 \mathrm{ppm} \mathrm{Mg}$ and measurement of silicon isotope ratios was carried out in Brest, France on a Neptune MC-ICP-MS (Thermo Scientific) (see Table 1 for operating conditions). Values of ${ }^{30} \mathrm{Si} /{ }^{28} \mathrm{Si}$ and ${ }^{29} \mathrm{Si} /{ }^{28} \mathrm{Si}$ were initially corrected for instrumental mass bias using Mg correction (Cardinal et al., 2003), for example:

$\left(\frac{{ }^{30} \mathrm{Si}}{{ }^{28} \mathrm{Si}}\right)_{\text {corr }}=\left(\frac{{ }^{30} \mathrm{Si}}{{ }^{28} \mathrm{Si}}\right)_{\text {meas }} \times\left(\frac{{ }^{30} \mathrm{Si}_{\mathrm{AM}}}{{ }^{28} \mathrm{Si}_{\mathrm{AM}}}\right)^{\varepsilon_{\mathrm{Mg}}}$,

where $\left({ }^{30} \mathrm{Si} /{ }^{28} \mathrm{Si}\right)$ corr (the corrected ratio of ${ }^{30} \mathrm{Si}$ to ${ }^{28} \mathrm{Si}$ ) is calculated from $\left({ }^{30} \mathrm{Si} /{ }^{28} \mathrm{Si}\right.$ ) meas (the measured ratio of ${ }^{30} \mathrm{Si}$ to ${ }^{28} \mathrm{Si}$ ), ${ }^{30} \mathrm{Si}_{\mathrm{AM}}$ and ${ }^{28} \mathrm{Si}_{\mathrm{AM}}$ (the atomic masses of ${ }^{30} \mathrm{Si}$ to ${ }^{28} \mathrm{Si}$ ), and $\varepsilon \mathrm{Mg}$, which has been calculated from the beam intensities at mass 25 and 26 :

$\varepsilon_{\mathrm{Mg}}=\ln \left[\frac{\frac{{ }^{25} \mathrm{Mg}_{A}}{{ }^{26} \mathrm{Mg}_{A}}}{\left(\frac{{ }^{25} \mathrm{Mg}}{26 \mathrm{Mg}}\right)_{\text {meas }}}\right] \div \ln \left[\frac{{ }^{25} \mathrm{Mg}_{\mathrm{AM}}}{{ }^{26} \mathrm{Mg}_{\mathrm{AM}}}\right]$,

where ${ }^{25} \mathrm{Mg}_{A} /{ }^{26} \mathrm{Mg}_{A}$ is the ratio expected based on the known natural abundances of the isotopes, $\left({ }^{25} \mathrm{Mg} /{ }^{26} \mathrm{Mg}\right)_{\text {meas }}$ is the ratio that was measured, and ${ }^{25} \mathrm{Mg}_{\mathrm{AM}}$ and ${ }^{26} \mathrm{Mg}_{\mathrm{AM}}$ are the atomic masses of ${ }^{25} \mathrm{Mg}$ and ${ }^{26} \mathrm{Mg}$.

Measurements of samples occurred between measurements of the standard NBS28, with each reported value consisting of three full measurements of a standard and two full measurements of a sample, with the values reported as $\delta^{30} \mathrm{Si}$ :

$\delta^{30} \mathrm{Si}=\frac{R_{\text {sam }}-R_{\text {std }}}{R_{\text {std }}} \times 10^{3}$,

where $R_{\text {sam }}$ is the Mg-corrected sample ${ }^{30} \mathrm{Si} /{ }^{28} \mathrm{Si}$ and $R_{\text {std }}$ the $\mathrm{Mg}$-corrected ratio for NBS28.

The precision on individual measurements of $\delta^{30} \mathrm{Si}$ was typically $\pm 0.04 \%$ o ( $1 \sigma$ standard deviation). The long-term precision (also $1 \sigma \mathrm{SD}$ ) for the procedure (i.e. including the column chemistry) was $\pm 0.07 \%$. Backgrounds and procedural blanks were both less than $1 \%$ of the sample signal. Measured values fell along the expected mass-dependent fractionation line $\delta^{30} \mathrm{Si}=\left(\delta^{29} \mathrm{Si}\right) 1.93$.

\subsection{Model}

To better appreciate the processes controlling the behaviour of $\delta^{30} \mathrm{Si}$ on the Kerguelen Plateau, we built a one-box model of the silica cycle in the surface mixed layer in this area, as described in detail in the following sections. Among other things, this model takes into consideration seasonal variation in the depth of the mixed layer using techniques developed in previous modelling studies (Evans and Parslow, 1985; Fasham et al., 1990; Platt et al., 2003). As such, the model was parameterised in part by using data from the slightly offplateau KERFIX time series site, and the model results were 


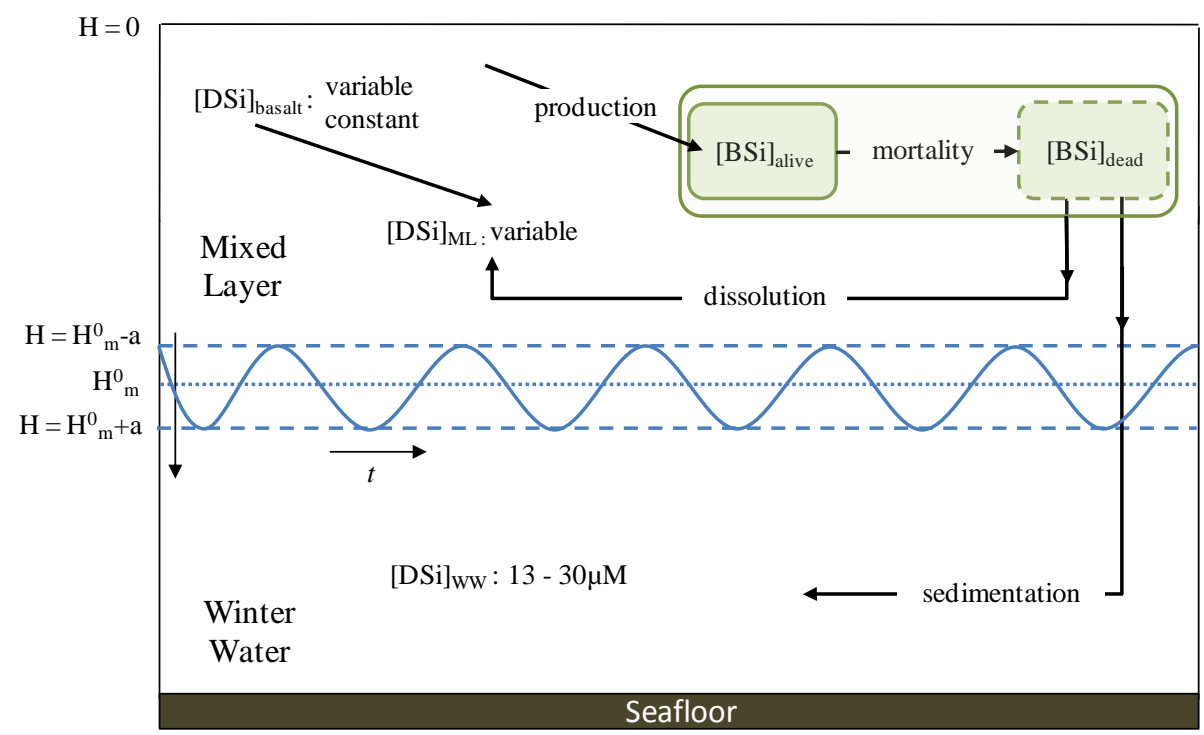

Fig. 2. Schematic representation of the box model, adapted from Platt et al. (2003). Dissolved silicon in the mixed layer (DSi $\mathrm{ML}_{\text {) }}$ is supplied by the Winter Water (WW) through mixing, by the dissolution of non-living diatoms $\left(\mathrm{BSi}_{\mathrm{D}}\right.$ ) in the mixed layer (ML), and, in some runs, by

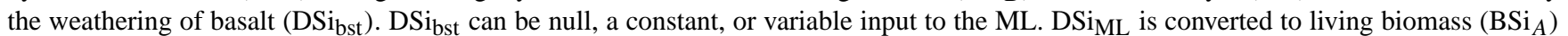
during diatom growth. $\mathrm{BSi}_{\mathrm{D}}$ is produced by mortality of $\mathrm{BSi}_{A} \cdot \mathrm{BSi}_{\mathrm{D}}$ is exported by sedimentation and by mixing process, while $\mathrm{BSi}_{A}$ is not allowed to sink. Concentrations of $\mathrm{BSi}_{A}$ and $\mathrm{BSi}_{\mathrm{D}}$ can be diluted by mixing and losses can be incurred by deepening of the ML. The ML depth $\left(H_{\mathrm{m}}\right)$ throughout the year is based on KERFIX data (Jeandel et al., 1998) following a time step $t$ of $0.05 \mathrm{~d}^{-1}$.

Table 1. Operating conditions for the Neptune MC-ICP-MS.

\begin{tabular}{ll}
\hline Resolution & Medium \\
\hline Sensitivity & $\sim 6 \mathrm{~V} \mathrm{ppm}^{-1}$ \\
Forward power & $1200 \mathrm{~W}$ \\
Accelerating voltage & $10 \mathrm{kV}$ \\
Cool gas & $15.5 \mathrm{~L} \mathrm{~min}^{-1}$ \\
Auxiliary gas & $0.8 \mathrm{~L} \mathrm{~min}^{-1}$ \\
Sample gas & $1 \mathrm{~L} \mathrm{~min}^{-1}$ \\
Sampler cone & Standard Ni cone \\
Skimmer cone & Standard Ni cone \\
Desolvator & Apex $(\mathrm{ESI})$ \\
Nebulizer & $60 \mu \mathrm{L} \mathrm{min}$ \\
& PFA microconcentric \\
\hline
\end{tabular}

compared to data from KERFIX and from stations located in different areas of the plateau in order to assess whether or not the model was behaving in a realistic manner. The purpose of this modelling exercise was thus not to obtain an exact match with the Kerguelen Plateau data, but to create a reasonably realistic model of silica cycling that could be used to explore the effects of different processes on the cycling of silicon isotopes.

\subsubsection{Model structure}

We used a simple box model to simulate the main features of the seasonal variations in DSi and BSi observed in the gen- eral vicinity of the Kerguelen Plateau. The model consisted of 1 variable depth box (Fig. 2), the mixed layer (ML), which is the sunlit (euphotic) zone where phytoplankton grow. The model was forced using the observed climatology of (1) the ML depth, (2) the concentration of DSi below the ML, and (3) the light intensity at the surface around the KERFIX time series station located at the edge of the Kerguelen Plateau $\left(50^{\circ} 40^{\prime} \mathrm{S}, 68^{\circ} 25^{\prime} \mathrm{E}\right)$ (Jeandel et al., 1998; Park et al., 1998a; Fasham et al., 2006). This station sits at the "upstream" side of the plateau where water depths are $>1500 \mathrm{~m}$ and is thus not a true "on plateau" location, but the KERFIX data set is the only 5-year, fairly continuous, seasonally resolved data set available for this area and provides a reasonable basis from which to explore the seasonal dynamics that control the changes in the $\delta^{30} \mathrm{Si}$ of DSi and BSi in surface waters. The small intrinsic time step $\left(0.05 \mathrm{~d}^{-1}\right)$ utilised in the modelling allows consideration of the model as if all processes (mixing, production, dissolution, etc) occurred concurrently. For each simulation, the model was run from 1 July (austral winter) until 30 June. Model spin-up was attained after the 3rd year; the results given in this paper are from year 6 of each model run.

Following Fasham et al. (1990), the ML was considered biologically homogeneous. The depth of the ML varied from 72 to $215 \mathrm{~m}$, depending on the time of year, in accordance with the data from KERFIX (Jeandel et al., 1998). The deepening of the mixed layer via convective overturning in autumn diluted the ML diatom biomass and replenished the surface box with DSi (whose concentration decreased during 
spring and summer because it was used for diatom growth). Conversely, when the mixed layer shoaled, there was no dilution of biomass and nutrient input to the ML occurred only through diffusion. BSi was produced only in the ML and was not returned from WW to the surface box via mixing. The concentration of DSi in the WW added to the ML was allowed to vary through the seasons based on DSi data from KERFIX. The isotopic composition $\left(\delta^{30} \mathrm{Si}\right)$ of the $\mathrm{WW}$, however, was fixed at $1.60 \%$, representing an average between values from the KEOPS data set $(1.80 \pm 0.24 \%$ (Fripiat et al., 2011b)) and $+1.40 \pm 0.04 \%$ o from CTD 8 (see results).

For the sake of simplicity and because the concentrations of the other macronutrients are never low enough in this region to be limiting to phytoplankton growth (Jacques, 1983; Sommer, 1986), DSi was the only nutrient represented in this model. In addition, the diatoms (in the form of biogenic silica, BSi) were the only phytoplankton represented as they are the main group influencing the silica cycle in the modern day ocean (Jeandel et al., 1998; Tréguer and De La Rocha, 2013).

BSi production in the ML was governed by the concentration of living BSi, the DSi concentration, and the availability of light (which depended on day length and ML depth). BSi was lost from the ML through both sinking (export) or dissolution back to DSi in the ML. Thus changes in the concentrations of DSi and BSi in the ML were controlled by a combination of physical processes (mixing, BSi dissolution, and BSi sinking) and biological processes (DSi uptake, BSi production, and diatom mortality).

\subsubsection{Model equations}

\section{Equations for change in concentrations of DSi and BSi}

Temporal changes in the concentrations of DSi and biogenic silica ( $\mathrm{BSi}_{A}$ for living diatoms, $\mathrm{BSi}_{D}$ for dead diatoms) are written:

$$
\begin{aligned}
& \frac{\mathrm{dDSi}}{\mathrm{d} t}=M_{\mathrm{bst}}+M_{\mathrm{WW}}^{\mathrm{DSi}}-P+D, \\
& \frac{\mathrm{dBSi}_{A}}{\mathrm{~d} t}=-M_{\mathrm{WW}}^{\mathrm{BSiA}}+P-M_{t}, \\
& \frac{\mathrm{dBSi} D}{\mathrm{~d} t}=-M_{\mathrm{WW}}^{\mathrm{BSiD}}+M_{t}-D-E .
\end{aligned}
$$

In Eq. (4), $M_{\text {bst }}\left(\mu \mathrm{mol}-\mathrm{Si} \mathrm{L}^{-1}\right)$ is the quantity of DSi input from the basalt weathering. Basalt input is zero, constant, or variable depending on the run. The constant input $\left(0.001103 \mu \mathrm{mol} \mathrm{L}^{-1}\right.$ per time step) sums to an amount equivalent to $10 \%$ of the yearly total DSi input from the WW while the variable input is a quantity equal to $10 \%$ of the WW input at each time step. In all equations, $M_{\mathrm{WW}}$ is the mixing of DSi or BSi between the WW and the ML (through diffusion and entrainment). In Eqs. (4) and (5) $P$ is the production of BSi in the ML, and $D$ is BSi dissolution. Finally, in Eqs. (5) and (6), $M_{\mathrm{t}}$ is the amount of dead diatom biomass and $E$ is the quantity of dead diatom biomass exported out of the ML. Each of these processes is described below.

Mixing $\left(M_{\mathrm{WW}}\right)$ is parameterised in the same manner for $\mathrm{BSi}_{A}$ and $\mathrm{BSi}_{\mathrm{D}}$ according to (Evans and Parslow, 1985; Fasham et al., 1990). For DSi, this term is written as

$M_{\mathrm{WW}}^{\mathrm{DSi}}=\left(\left(\mathrm{DSi}_{\mathrm{WW} t}-\mathrm{DSi}_{\mathrm{ML} t-1}\right) \times\left(\frac{m}{H_{t-1}}+\frac{\max \left(\left(\frac{H_{t-1}-H_{t}}{\mathrm{~d} t}\right), 0\right)}{H_{t-1}}\right)\right)$,

where DSiww and $\mathrm{DSi}_{\mathrm{ML}}$ are, respectively, the DSi concentrations in the Winter Water and mixed layer, $m$ is the mixing coefficient (in units of $\mathrm{md}^{-1}$ ), $H$ is the depth, in $\mathrm{m}$, of the mixed layer at time $t(\mathrm{~d})$, and $\left(\mathrm{DSi}_{\mathrm{WW}}-\mathrm{DSi}_{\mathrm{ML}}\right)$ is the gradient of concentration at the base of ML (Evans and Parslow, 1985; Fasham et al., 1990). This equation takes into account vertical mixing at the boundary between the two water masses and the motile and non-motile entities (Evans and Parslow, 1985; Fasham et al., 1990). This results in an increased concentration of DSi due to vertical mixing in the ML when mixed layer depth deepens, and in input of DSi to the ML from diffusive mixing only when the mixed layer depth shoals (Platt et al., 2003). In the model, the depth of the mixed layer $(H)$ at each time $t$ is calculated by interpolating monthly averaged data from the KERFIX time series station (Jeandel et al., 1998; Park et al., 1998a; Fasham et al., 2006). Similarly, seasonal variations of the DSi concentration in the Winter Water (DSiww) are calculated using monthly averaged data from KERFIX (http://www.obs-vlfr. $\mathrm{fr} / \mathrm{cd} \_$rom_dmtt/kfx_main.htm). The mixing of BSi is handled in exactly the same way as DSi (see Eq. 5), although the concentration of BSi in the WW is assumed to be $0 \mu \mathrm{mol} \mathrm{L}{ }^{-1}$, so that $\mathrm{BSi}$ is not entrained into the ML from WW during mixing.

The second process $\left(P, \mu\right.$ mol-Si L $\left.\mathrm{L}^{-1} \mathrm{~d}^{-1}\right)$ represents the diatom growth rate, or the production of $\mathrm{BSi}_{A}$. It is written as

$P=\mu_{\max } \times\left[\frac{\mathrm{DSi}}{\mathrm{DSi}+K_{\mathrm{Si}}} \times\left(1-\left(\exp \left(\frac{-\varphi_{P} \times \overline{I_{H, t}}}{\mu_{\max }}\right)\right)\right)\right] \times \mathrm{BSi}_{\mathrm{A}}$

In this equation, the diatom growth rate is governed by the availability of DSi and light by a multiplicative limitation term (Paasche, 1973). The maximal growth rate is $\mu_{\max }\left(\mathrm{d}^{-1}\right)$ and $K_{\mathrm{Si}}\left(\mu \mathrm{mol} \mathrm{L}{ }^{-1}\right)$ is the half-saturation constant for silicon uptake.

The $\mu_{\max }$ of $1.5 \mathrm{~d}^{-1}$ and the $K_{\mathrm{Si}}$ of $4 \mu \mathrm{M}$ were selected according to Sarthou et al. (2005, and references therein) as typical values for the maximal growth rate of diatoms and for the half-saturation constant associated with diatom uptake of silicic acid. These values can be, of course, quite different depending on the diatom species and physiological condition. For example, $K_{\mathrm{Si}}$ values may range from relatively low to values high enough to hold diatoms in a state of chronic growth rate limitation by silicic acid (Brzezinski and Nelson, 1996). $K_{\mathrm{Si}}$ values recently measured by Mosseri 
et al. (2008) for large diatoms $>10 \mu \mathrm{m}$ on the Kerguelen Plateau were as high as 4 to $57 \mu \mathrm{M}$, although non-linear uptake behaviour at high DSi concentrations and some scatter in the data at lower concentrations yielded considerable uncertainties in the curve fits used to generate the $K_{\mathrm{Si}}$ values. In light of this, we tested the sensitivity of the model to these coefficients (see results sections).

The second part of the equation accounts for light limitation, with $\overline{I_{H}}, \mathrm{~W} \mathrm{~m}^{-2}$ being the mean intensity of light in the mixed layer and $\varphi_{P}\left(\mathrm{~d}^{-1}\left(\mathrm{~W} \mathrm{~m}^{-2}\right)^{-1}\right)$ being the affinity of the phytoplankton for light (Platt and Jassby, 1976). The mean light intensity at time $t$ is calculated using the Beer Lambert law of light extinction:

$\overline{I_{H, t}}=\frac{1}{H_{t}} \int_{z=0}^{z=H_{t}} I_{0, t} \exp ^{\left(-K_{\mathrm{PAR}, t} z\right)} \mathrm{d} z$

which gives:

$\overline{I_{H, t}}=\left(\frac{I_{0, t}}{H_{t}}\right) \times\left(\frac{1-\exp \left(-K_{\mathrm{PAR}, t} \times H_{t}\right)}{K_{\mathrm{PAR}, t}}\right)$.

In Eqs. (9) and (10), $\mathrm{H}_{t}$ is the depth of the mixed layer (m), $I_{0, t}$, is the photosynthetically available radiation (PAR) at the surface of the ocean (in $\mathrm{W} \mathrm{m}^{-2}$ ), and $K_{\mathrm{PAR}, t}\left(\mathrm{~m}^{-1}\right)$ is the extinction coefficient for PAR.

A climatology of the mean daily PAR at the surface of the ocean, $I_{0, t}$ was built using predicted downward solar radiation from the European Centre for Meteorological Weather Forecast (ECMWF, in Fasham et al., 2006)

$I_{0, t}=\frac{(130+20)}{2}+55 \times \sin \left(2 \times \pi \times \frac{t}{365}+243\right)$.

In Eq. (10), $K_{\mathrm{PAR}, t}$ was calculated using the formulation of Nelson and Smith (1991):

$K_{\mathrm{PAR}, t}=0.04+0.0088 \times \mathrm{Chl}_{a, t}+0.054 \times \mathrm{Chl}_{a, t}^{2 / 3}$.

In the model, the biomass of chlorophyll a, Chl $a_{t}$, was calculated from the BSi concentration using the molar ratios $\mathrm{Si}: \mathrm{N}$ of $4: 1$ (a typical value for the Southern Ocean (Pondaven et al., 1998), especially given the heavy silicification of diatoms like Fragilariopsis kerguelensis) and C: N of 106: 16 (the Redfield ratio), and a mass ratio of $\mathrm{C}$ : Chlorophyll of $80: 1$ (Chan, 1980) as follows:

$\mathrm{Chl}_{a, t}=\mathrm{BSi}_{A} \times \frac{\mathrm{C}}{\mathrm{Si}} \times 12 \times \frac{\mathrm{Chl}_{a}}{\mathrm{C}}$.

$\mathrm{Si}: \mathrm{N}$ and $\mathrm{C}: \mathrm{N}$ values are quite variable in nature, especially under conditions of silicon, light, and iron limitation. Use of different values would have the ultimate effect of either increasing or decreasing the phytoplankton growth rate, depending on the values used.

The last parameter of Eq. (4), $D\left(\mu \mathrm{mol}-\mathrm{Si} \mathrm{L}^{-1} \mathrm{~d}^{-1}\right)$, accounts for dissolution of $\mathrm{BSi}$. In the model, only dead diatoms $\left(\mathrm{BSi}_{\mathrm{D}}\right)$ are allowed to dissolve. It is calculated following Nugraha et al. (2012). The fraction of BSi dissolved in the ML, $\overline{\mathrm{SR}}$, depends on two parameters, the specific remineralisation rate of detritus $\left(\tau, \mathrm{d}^{-1}\right)$ and the sinking velocity of particles $\left(V, \mathrm{~m} \mathrm{~d}^{-1}\right)$. The dissolution rate chosen, following Demarest et al. (2009), was $0.035 \mathrm{~d}^{-1}$, a value which was observed for surface samples during the early stage of BSi dissolution (the first $0-10 \%$ of dissolution of the biogenic silica). This value sits within the range of the in vivo dissolution rates measured in the Southern Ocean, being close to $0.04 \mathrm{~d}^{-1}$, the minimum dissolution rate measured by Beucher et al. (2004) in the Pacific sector, but generally higher than the rates of 0.01 to $0.04 \mathrm{~d}^{-1}$ measured by Nelson and Gordon (1982) in austral spring in the ACC of the Pacific sector of the Southern Ocean. In the box model, we derived estimates of $\overline{\mathrm{SR}}$ using the following relationships:

$\overline{\mathrm{SR}}=\frac{1}{H_{t}} \int_{z=0}^{z=H_{t}}\left(1-e^{\left(-\tau x \frac{\left(H_{t}-z\right)}{V}\right)}\right) p(z) \mathrm{d} z$,

where $H$ is the depth of the surface layer and $p(z)$ is a probability distribution for particles in the water column. For simplicity, we assumed that BSi was homogeneously distributed between $z=0$ and $z=H$. Integration of this equation between $z=0$ and $z=H$ yielded

$\overline{\mathrm{SR}}=1-\left(1-e^{\frac{-\tau H}{V}}\right) \frac{V}{\tau H}$.

The sinking velocity $V$ is calculated as follows:

$V=V_{\min }+\frac{V_{\max }}{1+\left(\frac{\mathrm{BSi}_{T t-1}}{\beta}\right)^{-2}}$,

with $V_{\min }$ and $V_{\max }$ being the minimum and the maximum sinking velocities allowed (in $\mathrm{md}^{-1}$ ); $\beta$ is the $\mathrm{BSi}$ concentration $\left(\mu \mathrm{mol}-\mathrm{Si} \mathrm{L}^{-1}\right)$ value at the inflexion point of this function, i.e. the concentration above which the sinking rate increases rapidly from its minimum value $\left(1 \mathrm{~m} \mathrm{~d}^{-1}\right)$ and converges to the maximum sinking velocity $\left(20 \mathrm{~m} \mathrm{~d}^{-1}\right)$. The choice of the minimum and maximum sinking velocity was made based on the sinking speeds of individual cells versus aggregates $>0.5 \mathrm{~mm}$ (marine snow). According to Smayda (1970), individual cells will generally sink slowly, e.g. $\sim 1 \mathrm{~m} \mathrm{~d}^{-1}$, while aggregates, being larger, sink faster, some more than $100 \mathrm{~m} \mathrm{~d}^{-1}$ (Alldredge and Gotschalk, 1988). We have set the upper limit here at $20 \mathrm{~m} \mathrm{~d}^{-1}$. Thus:

$D=\overline{\mathrm{SR}} \times M_{t}$.

The mortality term of living diatoms $\left(\mathrm{BSi}_{A}\right)$ is written as

$M_{t}=\left(g \times \frac{\mathrm{BSi}_{A}}{\left(\mathrm{BSi}_{A}+0.1\right)} \times \mathrm{BSi}_{A}\right)$,

with $g$ being the mortality rate of diatoms $\left(\mathrm{d}^{-1}\right)$. As higher trophic levels (i.e. zooplankton) are not explicitly included in 
Table 2. Parameter values used in the model.

\begin{tabular}{llll}
\hline Symbol & Parameter & Unit & Value \\
\hline$\mu_{\max }$ & Maximum growth rate of phytoplankton & $\mathrm{d}^{-1}$ & $1.5^{\mathrm{a}}$ \\
$K_{\mathrm{Si}}$ & Half-saturation constant for Si-limited growth & $\mu \mathrm{mol} \mathrm{L}^{-1}$ & 3.9 \\
$\mathrm{~m}$ & Mixing coefficient between ML and WW & $\mathrm{m} \mathrm{d}^{-1}$ & $\mathrm{H} / 50$ \\
$g$ & Mortality rate of phytoplankton & $\mathrm{d}^{-1}$ & $0.192^{\mathrm{b}}$ \\
$\tau$ & BSi dissolution rate & $\mathrm{d}^{-1}$ & $0.035^{\mathrm{c}}$ \\
$V_{\min }$ & Minimal sinking speed & $\mathrm{m} \mathrm{d}^{-1}$ & 1 \\
$V_{\max }$ & Maximal sinking speed & $\mathrm{m} \mathrm{d}^{-1}$ & 20 \\
$\delta^{30} \mathrm{Si}_{\text {bst }}$ & Isotopic composition of DSi released during basalt weathering & $\%$ oo & $-1.00+1.80^{\mathrm{d}}$ \\
$\delta^{30} \mathrm{Si}_{\mathrm{ww}}$ & Isotopic composition of DSi from the WW & $\%$ & 1.60 \\
& & & \\
\hline
\end{tabular}

a Sarthou et al. (2005); ${ }^{\text {b }}$ Tyrrell (1999); ${ }^{\text {c }}$ Demarest (2009); ${ }^{\text {d }}$ Douthitt (1982); Ziegler et al. (2005); and Georg et al. (2007b)

Table 3. Abbreviations and subscripts used in the model equations.

\begin{tabular}{lll}
\hline Variables & Abbreviation & Units \\
\hline DSi winter water & $\mathrm{DSi}_{\mathrm{WW}}$ & \\
DSi mixed layer & $\mathrm{DSi}_{\mathrm{ML}}$ & \\
DSi total & $\mathrm{DSi}_{\mathrm{T}}$ & \\
DSi basalt & $\mathrm{DSi}_{\text {bst }}$ & $\mu \mathrm{mol} \mathrm{L}^{-1}$ \\
$\mathrm{BSi}$ dead diatom & $\mathrm{BSi}_{\mathrm{D}}$ & \\
BSi alive diatom & $\mathrm{BSi}_{A}$ & \\
BSi total & $\mathrm{BSi}_{\mathrm{T}}$ & \\
\hline After mixing process & $\mathrm{m}$ & \\
After production & $\mathrm{p}$ & \\
After death & $\mathrm{d}$ & Dimensionless \\
After dissolution & $\mathrm{ds}$ & \\
After sinking & $\mathrm{s}$ & \\
\hline
\end{tabular}

the model, a quadratic formulation was used to parameterise grazing on diatoms (see for example Steele and Henderson, 1995). The grazing term selected was $0.20 \mathrm{~d}^{-1}$ (i.e. 70/365) (Tyrrell, 1999; Nugraha et al., 2012).

The final term in Eq. (6), E ( $\mu$ mol-Si $\left.\mathrm{L}^{-1} \mathrm{~d}^{-1}\right)$, describes the loss of dead diatoms due to sinking out of the mixed layer.

$E=\frac{V_{t}}{H_{t}} \times \mathrm{BSi}_{D}$

The parameter values utilised in the modelling are given in Table 2.

\section{Equations for change in the isotopic composition of DSi and BSi}

In the model, the ratio $(R)$ of silicon isotopes $\left({ }^{30} \mathrm{Si} /{ }^{28} \mathrm{Si}\right)$ of DSi and BSi was calculated based on mass balance and by isotopic fractionation during processes for which this is known to be important. For example, the change in the ${ }^{30} \mathrm{Si} /{ }^{28} \mathrm{Si}$ of DSi of the ML with time is influenced by mixing with the WW, removal of DSi for BSi production, the dissolution of $\mathrm{BSi}$, and in a subset of model runs, input from the subaerial and/or submarine weathering of basalt:

$$
\begin{aligned}
& \frac{\mathrm{dRDSi}}{\mathrm{d} t}= \\
& \frac{\left(\left([\mathrm{DSi}]_{b s t} \times \mathrm{RDSi}_{\mathrm{bst}}\right)+\left([\mathrm{DSi}]_{m} \times \mathrm{RDSi}_{m}\right)-\left(\left[\mathrm{DSi}_{p} \times \mathrm{RDSi}_{p}\right)+\left(\left[\mathrm{DSi}_{\mathrm{ds}} \times \mathrm{RDSi}_{\mathrm{ds}}\right)\right)\right.\right.}{\left[\mathrm{DSi}_{T}\right]} .
\end{aligned}
$$

It was difficult to ascribe a precise value for the silicon isotope ratio produced through basalt weathering $\left(\operatorname{RDSi}_{b s t}\right)$ because to date there has been no study of isotope fractionation during the submarine weathering of basalt. Several studies have noted the typical $\delta^{30} \mathrm{Si}$ of basalt itself of -0.29 to $-0.50 \%$ (Ziegler et al., 2005; Georg et al., 2007b; Abraham et al., 2008; Bern et al., 2010; Opfergelt and Delmelle, 2012; Pogge von Strandmann et al., 2012). Other studies provide data on the $\delta^{30} \mathrm{Si}$ of DSi produced during the subaerial weathering of basalt, yielding values ranging from -1.0 to $+0.4 \%$. We have thus tested a range of values for the $\delta^{30} \mathrm{Si}$ of DSi from basalt weathering from -1.0 to $+0.7 \%$ (Ziegler et al., 2005; Georg et al., 2007a, b; Pogge von Strandmann et al., 2012).

Likewise, the change in the isotopic ratio of live $\mathrm{BSi}$ ( $\left.\mathrm{BSi}_{A}\right)$ over time represented a mixture of old and newly produced $\mathrm{BSi}_{A}$ (see Table 3 for abbreviation):

$\frac{\mathrm{dRBSi}_{A}}{\mathrm{~d} t}=\frac{\left(\left[\mathrm{BSi}_{A}\right]_{p} \times \mathrm{RBSi}_{A p}\right)}{\left[\mathrm{BSi}_{A}\right]_{T}}$.

Similarly, the change in the ${ }^{30} \mathrm{Si} /{ }^{28} \mathrm{Si}$ of dead diatoms $\left(\mathrm{BSi}_{D}\right)$ with time represents mass balance between inputs due to BSi production by live diatoms and to output due to the death of live diatoms and the dissolution of BSi:

$$
\begin{aligned}
& \frac{\mathrm{dRBSi}}{\mathrm{d} t}= \\
& \frac{\left(\left(\left[\mathrm{BSi}_{D}\right]_{p} \times \mathrm{RBSi}_{D p}\right)+\left(\left[\mathrm{BSi}_{D}\right]_{d} \times \mathrm{RBSi}_{D d}\right)-\left(\left[\mathrm{BSi}_{D}\right]_{d s} \times \mathrm{RBSi}_{D d s}\right)\right)}{\left[\mathrm{BSi}_{D}\right]_{T}} .
\end{aligned}
$$

Isotope fractionation occurred during the production of live BSi from DSi and during the dissolution of non-living $\mathrm{BSi}$. Isotope fractionation during BSi production within each time step was calculated following Rayleigh distillation. Although given the very small time step used, the DSi reservoir 
was never depleted by more than $1.4 \%$ during one time step (i.e. the inclusion of Rayleigh distillation in the calculation had an insignificant effect on the model outcome):

$\operatorname{RBSi}_{A}=\operatorname{RDSi}_{m} \times \frac{\left(1-f^{\alpha_{p}}\right)}{(1-f)}$,

where $f$ is the remaining fraction and $\alpha_{p}$ is the isotopic fractionation factor of 0.9988 during biogenic silica production (De La Rocha et al., 1997).

Likewise, fractionation during the dissolution of nonliving BSi occurred, producing new DSi and altering the isotopic composition of the dead BSi pool as follows:

$\operatorname{RDSi}=\operatorname{RBSi}_{D d} \times \frac{\left(1-f^{\propto_{d}}\right)}{(1-f)}$,

with $\alpha_{d}$ the isotopic fractionation factor for biogenic silica dissolution set at either 1 (no fractionation) or 0.9995 (Demarest et al., 2009), depending on the run.

\section{Results and discussion}

\subsection{Concentration and $\delta^{30} \mathrm{Si}$ of DSi and BSi on the Kerguelen Plateau and at the Antarctic Divergence}

As expected, DSi concentrations in Southern Ocean surface waters increased southwards, ranging from $11 \mu \mathrm{M}$ in the surface layer at CTD8 located on the edge of the Kerguelen Plateau to $56 \mu \mathrm{M}$ at CTD1 in the Antarctic Divergence in the Atlantic sector of the Southern Ocean (Fig. 3a) (Dafner and Mordasova, 1994; Brzezinski et al., 2001; Varela et al., 2004; De La Rocha et al., 2011). As also expected based on previous studies (Brzezinski et al., 2001; Varela et al., 2004; Cardinal et al., 2005; Fripiat et al., 2011c), the isotopic composition of $\mathrm{DSi}\left(\delta^{30} \mathrm{Si}_{\mathrm{DSi}}\right)$ generally increased with decreasing DSi concentration, both at the surface (Fig. 4), and with depth in the water column (Fig. 3b), reflecting the effects of biological discrimination against the heavier isotopes during DSi uptake and/or BSi production.

The data from the CTD profiles can be pooled into three categories: DSi concentrations between 0 and $45 \mu \mathrm{M}$ (the surface mixed layer), DSi concentrations between 45 and $90 \mu \mathrm{M}$ (WW), and DSi concentrations $>90 \mu \mathrm{M}$ (Circumpolar Deep Water, CDW). The ${ }^{30} \mathrm{Si}_{\mathrm{DSi}}$ of the surface layer ranged between $+1.90 \%$ and $+2.39 \%$, the $\delta^{30} \mathrm{Si}_{\mathrm{DSi}}$ of $\mathrm{WW}$ ranged from $+1.20 \%$ o to $+1.65 \%$, and the $\delta^{30} \mathrm{Si}_{\mathrm{DSi}}$ of $\mathrm{CDW}$ varied from $+0.92 \%$ o to $+1.44 \%$, all in accordance with previous observations (De La Rocha et al., 2011; Fripiat et al., 2011b).

The $\delta^{30} \mathrm{Si}$ of surface water on the Kerguelen Plateau, between Kerguelen and Heard islands, has been observed to decrease from values of +2.7 to $+2.0 \%$ at DSi concentrations of 2 to $20 \mu \mathrm{M}$ in late January/early February (austral summer) (Fripiat et al., 2011b) to around $+1.8 \%$ at the end of March (early austral autumn) at DSi concentrations that are essentially equivalent $(4-17 \mu \mathrm{M})$ (samples $51-53$ and 58

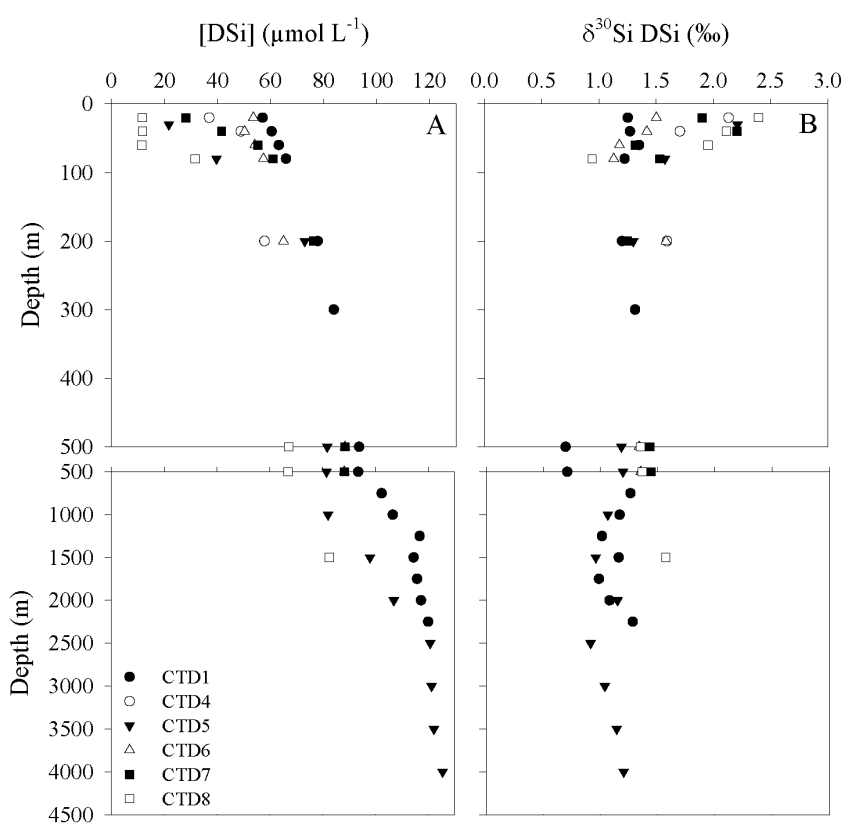

Fig. 3. Profiles of (A) DSi concentration data versus depth and (B) $\delta^{30} \mathrm{Si}_{\mathrm{DSi}}$ versus depth from the CTD stations.

in (De La Rocha et al., 2011)). This is not, however, true for the surface water samples taken at the same time just outside of the relatively shallow area $(<1000 \mathrm{~m})$ between Kerguelen and Heard islands (surface transect samples 43-50 in De La Rocha et al., 2011) or at the edge of the plateau (surface values from CTD8 where the seafloor was at $2100 \mathrm{~m}$ ). These $\delta^{30} \mathrm{Si}$ values remain relatively high, around +2.3 to $+2.5 \%$, at DSi concentrations ranging from 10 to $25 \mu \mathrm{M}$. Together, these data are suggestive of a process which has lowered the surface water ${ }^{30} \mathrm{Si}$ without notably increasing DSi concentrations in the shallow, restricted circulation region of the Kerguelen Plateau and without lowering the $\delta^{30} \mathrm{Si}$ of DSi in surrounding surface waters more open to exchange with the waters of the Antarctic Circumpolar Current (ACC).

At the same time, the plot of $\delta^{30} \mathrm{Si}$ of DSi versus DSi concentration for all the Southern Ocean samples (Fig. 4) suggests that in general, the $\delta^{30} \mathrm{Si}$ values of DSi at concentrations below $20 \mu \mathrm{M}$ are somewhat variable and depressed. Isotope fractionation during DSi removal should result in values of $\delta^{30} \mathrm{Si}$ of DSi upwards of $+2.5 \%$ or $+3.0 \%$ at these low concentrations, based on either open system (continuous input) or closed system (single input) models for the evolution of $\delta^{30} \mathrm{Si}$ in the surface layer during the net growth of diatoms (De La Rocha et al., 1997; Varela et al., 2004). Instead, many $\delta^{30} \mathrm{Si}$ values from the Southern Ocean at DSi concentrations $<20 \mu \mathrm{M}$ fall between $+1.5 \%$ and $+2.5 \%$ (Fig. 4). While many of these values are the low values from the shallow region of the Kerguelen Plateau in March, not all of them are, suggesting that whatever process is at work, it is not unique to this somewhat special region. For example, data 


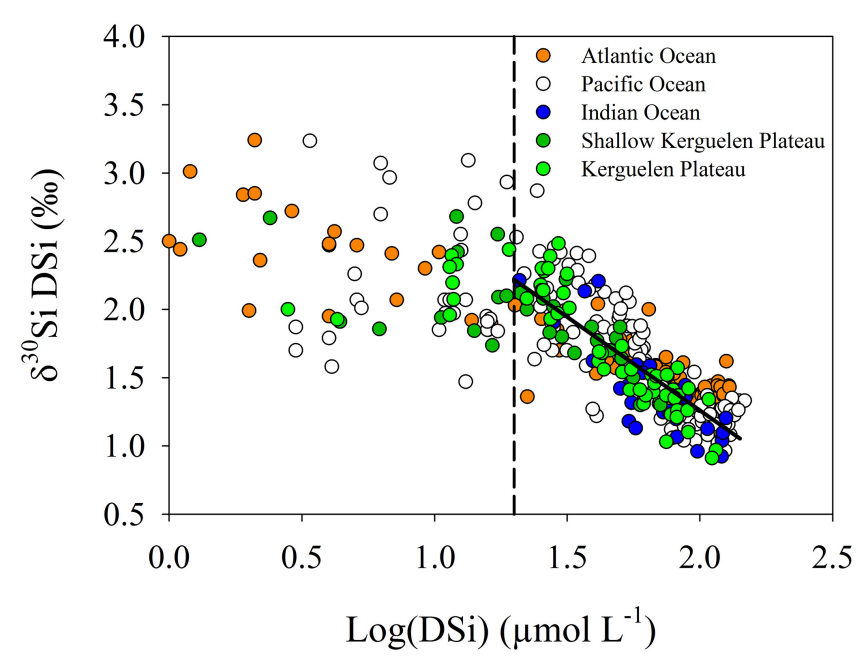

Fig. 4. The $\delta^{30} \mathrm{Si}$ DSi versus the $\log (\mathrm{DSi})$ of samples from the Southern Ocean from the Atlantic sector and the Indian sector (this study and De La Rocha et al., 2011; Fripiat et al., 2011a; de Souza et al., 2012b), the Kerguelen Plateau (De La Rocha et al., 2011; Fripiat et al., 2011b), and the Pacific sector (Varela et al., 2004; Cardinal et al., 2005; Cardinal et al., 2007). The dotted line occurs at a DSi concentration of $20 \mu \mathrm{M}$ and the solid line is the regression line for the data, except for the samples from the Kerguelen Plateau and from Cardinal et al. (2005), which are outliers $\left(y_{0}=-1.37 x\right.$ $+4.00, R_{\text {adjusted }}^{2}=0.64$ for $\left.p<0.001\right)$.

from the Antarctic Circumpolar Current (ACC) south of Tasmania (Cardinal et al., 2005) also have relatively low $\delta^{30} \mathrm{Si}$ values of +1.4 to $+2.3 \%$ at DSi concentrations as low as 1.8 to $18 \mu \mathrm{M}$.

There are at least three possible explanations for the low values of $\delta^{30} \mathrm{Si}$ of DSi observed.

First DSi input from basalt weathering on the LIP that is the Kerguelen Plateau may be reducing the surface water $\delta^{30} \mathrm{Si}$ values in the shallow region from the high postdiatom bloom values reported by Fripiat et al. (2011b). These authors observed some low $\delta^{30} \mathrm{Si}$ values (around $+1.90 \%$ o for DSi at 10 to $50 \mathrm{~m}$ ) very close to Heard Island, prompting them to suggest that basalt weathering would add DSi with a low $\delta^{30} \mathrm{Si}$, decreasing the average surface water value. Assuming the $\delta^{30} \mathrm{Si}$ of basalt of -0.3 to $-0.4 \%$ (Douthitt, 1982; Ding et al., 1996; Ziegler et al., 2005; Georg et al., 2007a; Georg et al., 2007b; Savage et al., 2011) and no fractionation during weathering, Fripiat et al. (2011b) estimated that $10 \pm 5 \%$ of the DSi would have had to come from basalt dissolution to explain the low $\delta^{30} \mathrm{Si}$ values near Heard Island. Data from isotopes of other elements (e.g. Nd) support this estimate (Jeandel et al., 2011; Oelkers et al., 2011), assuming their congruent release with Si during the submarine and/or subaerial weathering of basalt (an assumption that is unlikely to be true).

Another possibility is that the progressively more important recycling of silicon later in the growing season (and ex- port of BSi with a slightly elevated $\delta^{30} \mathrm{Si}$, due to fractionation during dissolution (Demarest et al., 2009)) causes the drop in $\delta^{30} \mathrm{Si}$ of DSi in these surface waters without increasing the DSi concentration. In the model of de Brauwere et al. (2012), because BSi production continues after the peak of the bloom, the post-peak of BSi should parallel the $\delta^{30} \mathrm{Si}$ of DSi (Fig. 8b), as in our model (Fig. 6). However, the $\delta^{30} \mathrm{Si}$ of BSi remains flat even as the $\delta^{30} \mathrm{Si}$ of DSi in the de Brauwere et al. (2012) model declines. This most likely reflects the increasing importance of dissolution in their model at this time to the point where the $\mathrm{D}: \mathrm{P}$ ratios exceed 1 . Thus in their model, the $\delta^{30} \mathrm{Si}$ of BSi becomes increasingly similar to that of DSi because fractionation during dissolution prevents a decline in the $\delta^{30} \mathrm{Si}$ of BSi in their model.

Lastly, the downward shift in $\delta^{30} \mathrm{Si}$ of DSi at low concentrations of DSi may be seasonal in nature, related to input of lower $\delta^{30} \mathrm{Si}$ of DSi from WW at the beginning of autumn occurring with no notable increase in ML DSi concentrations because of the continued, albeit minimal due to light limitation, production of $\mathrm{BSi}$.

We have used the box model approach to evaluate each of the three hypotheses mentioned above.

\subsection{The basic behaviour of the model}

\subsubsection{The predicted seasonal Si cycle around the Kerguelen Plateau}

As mentioned previously (see Sect. 2.2), the goal of the modelling was not specifically to reproduce the results from the KERFIX time series site or from the plateau depth profile and surface sampling stations, but to simulate a system that was behaving similarly enough to this general region to investigate the processes controlling the behaviour of silicon isotopes in the mixed layer throughout the course of the year. Our first benchmark for the model was for it to represent the main features of the annual silica cycle in the Southern Ocean in the general region around the Kerguelen Plateau, since that is where the input parameters and data for comparison with the model output come from. Figure 5 shows that the model indeed does a reasonable job of simulating an annual silica cycle typical of the Kerguelen Plateau and environs.

The annual maximum DSi concentration in the model ML $(24.5 \mu \mathrm{M})$ and the yearly minimum in the model BSi concentration $\left(1.19 \mu \mathrm{mol} \mathrm{L}^{-1}\right)$ occurred in spring (September) associated with the annual maximal mixed layer depth $(216 \mathrm{~m})$ (Fig. 5), as expected. Although the 5-year average KERFIX DSi concentrations $(15.77 \pm 2.95 \mu \mathrm{M})$ and BSi concentrations $\left(0.29 \pm 0.10 \mu \mathrm{mol} \mathrm{L}^{-1}\right)$ at this time are slightly lower, the differences are not alarming. The model successfully produced a spring bloom of phytoplankton, although by occurring in spring (November) and resulting in a maximal concentration of BSi of $4.90 \mu \mathrm{mol} \mathrm{L}^{-1}$, it was earlier and larger than the bloom observed at the KERFIX site (which typically attained BSi concentrations around $1.0 \mu \mathrm{mol} \mathrm{L}^{-1}$ ). The 

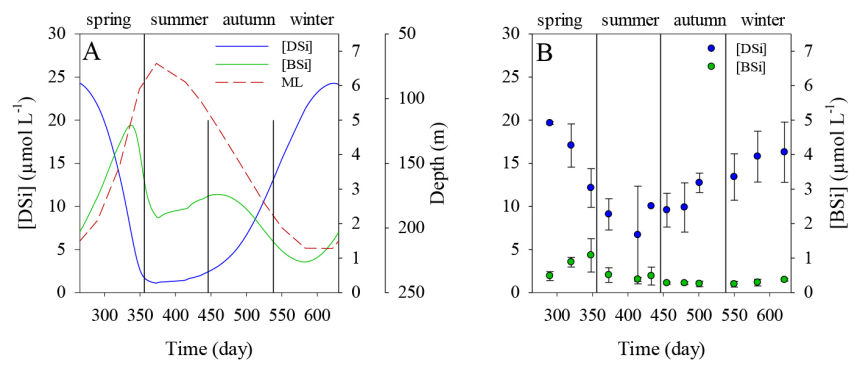

Fig. 5. Seasonal evolution of (A) modelled concentrations of dissolved silicon (DSi) and biogenic silica (BSi) shown alongside the mixed layer depth (ML) of the model and (B) monthly averaged DSi and BSi from the KERFIX data set (Jeandel et al., 1998).

model also produced a second bloom in early autumn (April), as expected from the onset of the seasonal deepening of the ML. This autumn bloom resulted in BSi concentrations of $2.86 \mu \mathrm{mol} \mathrm{L}^{-1}$.

Exact values for the modelled concentrations of DSi and $\mathrm{BSi}$ are sensitive to the values selected for DSi uptake kinetics and BSi dissolution rates, and the parameterisations of diatom mortality and BSi sinking. We certainly could have tuned these models to yield more perfectly matching results, but decided against this. The similarity obtained between modelled and measured values is good enough to use the model to consider the processes contributing to the day-today values of $\delta^{30} \mathrm{Si}$ in the ML.

The ratio of $\mathrm{BSi}$ dissolution to production $(\mathrm{D}: \mathrm{P})$ varied throughout the year in the model (Fig. 7a), ranging from a maximum of 0.64 in winter to a minimum of 0.19 in summer as diatom growth rates increased. This falls well within the range observed over various timescales (daily to annual) in the Southern Ocean (Tréguer and De La Rocha, 2013), with values $<0.3$ taken to reflect conditions during blooms (when rapid net production of $\mathrm{BSi}$ occurs) and the annual average $\mathrm{D}: \mathrm{P}(0.37)$ falling close to the roughly expected value of 0.5 .

The ratio between DSi uptake and supply also varied throughout the year, driven mostly by change in BSi production rates. Rates of BSi production (and therefore DSi uptake) peaked during the spring bloom, the time when the rate of DSi supply due to mixing was relatively low (Fig. 7c), resulting in high DSi uptake to supply ratios. The ratio of uptake and supply was lowest in early winter, not because of a high rate of DSi supply (by this time the ML had finished deepening and DSi concentrations were already close between the ML and the WW, resulting in little net modelled change in ML DSi concentration), but due to very low rates of BSi production (Fig. 7b). Over the course of the model year, the DSi uptake to supply ratio ranged from 0.5 to 7 .

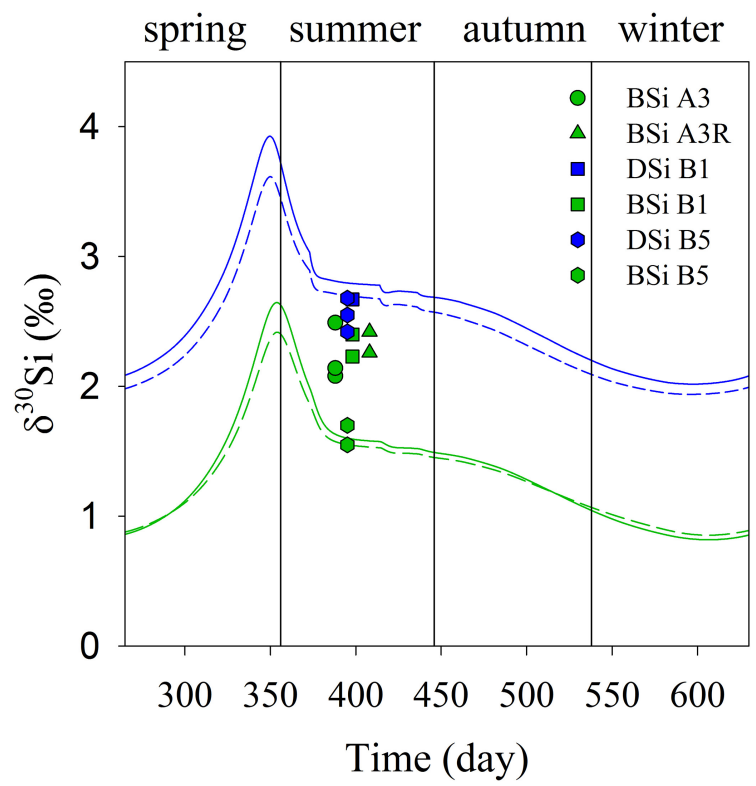

Fig. 6. Annual evolution of $\delta^{30} \mathrm{Si}_{\mathrm{DSi}}$ and $\delta^{30} \mathrm{Si}_{\mathrm{BSi}}$ in the model. Blue represents DSi and green represents BSi. Solid lines represent the initial run without fractionation during BSi dissolution and dotted lines are the simulation with fractionation during BSi dissolution. Data points are from KEOPS (Fripiat et al., 2011b).

\subsubsection{Model simulation without fractionation during BSi dissolution, and no input from basalt}

During the basic run of the model (no fractionation during BSi dissolution and no input from basalt), the $\delta^{30} \mathrm{Si}$ of DSi and BSi increased during spring growth to reach maximal values by the end of spring (from +2.0 to $+3.7 \%$ for DSi and from +0.8 to $+2.6 \%$ for BSi) (Fig. 6). These values steeply decreased during summer and continued to decline through autumn (from +2.6 to $+2.2 \%$ for DSi and from +1.5 to $+1.0 \%$, for $\mathrm{BSi}$ ), while DSi concentrations increased and BSi concentrations decreased due to a combination of mixing of DSi up into the ML and light limitation of phytoplankton growth.

If this basic model run represents the sum total of the processes influencing the isotopic composition and cycling of $\mathrm{DSi}$ and $\mathrm{BSi}$, several conclusions may be drawn.

The first is that there is a period of time, specifically during summer stratification, when the DSi concentration in the ML is at its annual minimum and relatively constant, but the $\delta^{30} \mathrm{Si}$ of the DSi is decreasing over time (Fig. 6b). This is due to diffusive input of low $\delta^{30} \mathrm{Si}$ DSi from WW into the ML, which brings down the average $\delta^{30} \mathrm{Si}$ of DSi in the ML. At the same time, Si-limited growth of diatoms is able to maintain the DSi concentration at a minimum determined by the DSi uptake kinetics of the diatom species present. Despite gross production of $\mathrm{BSi}$ at this time, $\mathrm{BSi}$ concentrations increased only slightly (from 0.30 to $0.42 \mu \mathrm{mol} \mathrm{L}^{-1} \mathrm{~d}^{-1}$ ), due to losses to sinking and dissolution that are nearly as great as 

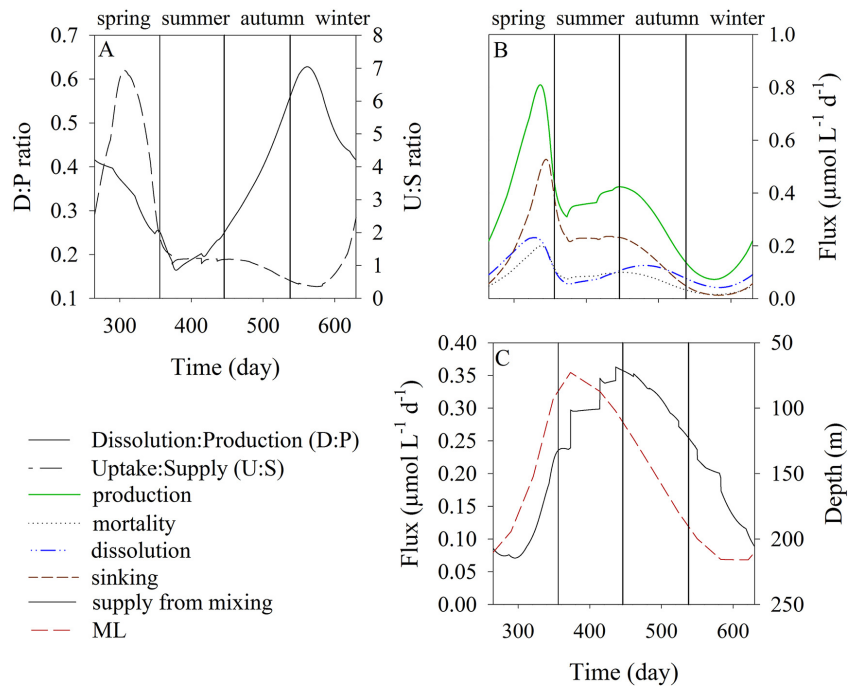

Fig. 7. Evolution of the main fluxes and ratios in the basic model run (with neither basalt input nor fractionation during biogenic silica dissolution); (A) variation of the ratio of Dissolution to Production and of the Uptake to Supply ratio during the year; (B) evolution of production, mortality, dissolution and sedimentation fluxes; (C) evolution of the DSi supply and the ML depth throughout the year.

the gains due to production. Thus the input of low $\delta^{30} \mathrm{Si}$ DSi from WW coupled with the export of BSi with a $\delta^{30} \mathrm{Si}$ lower than the $\delta^{30} \mathrm{Si}$ of the ML DSi drives down the $\delta^{30} \mathrm{Si}$ of the DSi without any increase in DSi concentrations. This alone would explain the lower $\delta^{30} \mathrm{Si}$ for ML DSi observed in early autumn by De La Rocha et al. (2011) compared to those in the middle of summer by Fripiat et al. (2011b). In principle then, neither basalt dissolution nor fractionation during $\mathrm{BSi}$ dissolution is necessary to attain this result.

The second thing to note is that in all likelihood, none of the published studies have sampled the Kerguelen Plateau, or anywhere else in the Atlantic and Indian sectors of the Southern Ocean, early enough in the growing season to capture the highest possible values for $\delta^{30} \mathrm{Si}$ in the mixed layer.

\subsubsection{Model run including fractionation during biogenic silica dissolution}

In some of the model runs, fractionation during $\mathrm{BSi}$ dissolution was allowed to occur with a fractionation $(\varepsilon)$ of $-0.55 \%$. At the full extent of expression of the fractionation, this would produce DSi with a $\delta^{30} \mathrm{Si}$ that was $-0.55 \%$ o compared to the BSi being dissolved. This fractionation resulted in a diminishment of the $\delta^{30} \mathrm{Si}$ of DSi in the model by roughly $0.2 \%$ o throughout the entire year (Fig. 7). Such fractionation during dissolution should lower the ${ }^{30} \mathrm{Si}$ of DSi recycled in the ML, while slightly increasing the $\delta^{30} \mathrm{Si}$ of $\mathrm{BSi}$ exported. Thus discrimination against the heavier isotopes during dissolution will pump Si of slightly higher ${ }^{30} \mathrm{Si}$
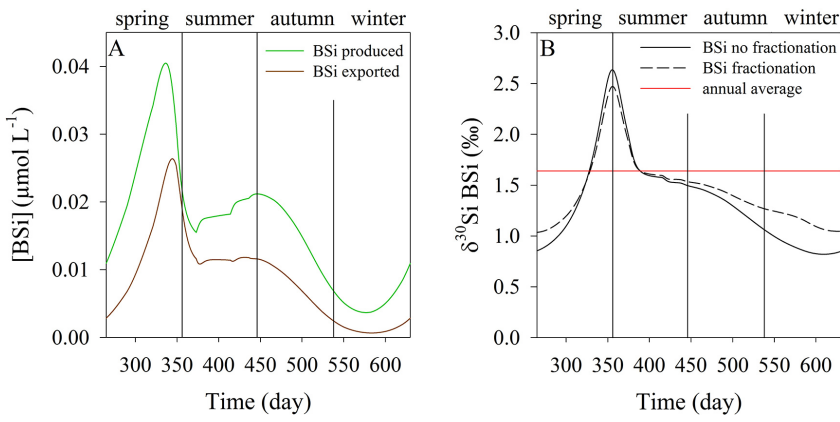

Fig. 8. (A) Annual evolution of the BSi production and the exported BSi outside of the ML, and (B) annual behaviour of the $\delta^{30} \mathrm{Si}$ of the BSi exported outside of the ML (on the sediment) from the initial run (without fractionation during BSi dissolution) and from the run with fractionation during dissolution. The red line represents the mass-weighted average value of the $\delta^{30} \mathrm{Si}$ of the $\mathrm{BSi}$ exported for the runs with and without fractionation during BSi dissolution (1.64 and $1.65 \%$, respectively).

out of the ML, while causing the retention of Si with slightly lower $\delta^{30} \mathrm{Si}$.

In contrast, the effect of fractionation during dissolution on the $\delta^{30} \mathrm{Si}$ of BSi did not occur evenly throughout the year, but was largely confined to the higher $\delta^{30} \mathrm{Si}$ values associated with the seasonal phytoplankton bloom. The bloom values were as much as $0.2 \%$ lower than they were without fractionation during dissolution, while the low $\delta^{30} \mathrm{Si}$ values associated with wintertime BSi were identical to those in the simulations without fractionation during BSi dissolution (Fig. 6). The overall result is a damping of the annual range of $\delta^{30} \mathrm{Si}$ of BSi.

The damping of the yearly range in $\delta^{30} \mathrm{Si}$ of ML BSi with fractionation during BSi dissolution is a key result, but for the moment it should be taken cautiously. Note, for example, that the winter values for the $\delta^{30} \mathrm{Si}$ of DSi in all the different simulations (Fig. 6) did not converge on the WW value of $1.6 \%$. In part this can be blamed on BSi production which occurs throughout the year and thus always consumes some DSi (Fig. 7a and b), elevating the surface water values of ${ }^{30} \mathrm{Si}$, even in winter. By itself, this is both reasonable and realistic; phytoplankton growth may slow to a crawl during winter, but it does not cease entirely. However, the failure of the $\delta^{30} \mathrm{Si}$ values for DSi in winter to drop all the way down to the WW value may also be partly an artefact of the modelling. In winter in the model, gross input of DSi into the ML is relatively low because the model tracks net input which decreases over the course of the winter as the DSi concentration of the WW and the ML become similar. In the real world, while there would also be little net input of DSi into the ML at this time, exchange of DSi between the ML and the large pool of WW would still occur vigorously, and the winter ML values of $\delta^{30} \mathrm{Si}$ of DSi in the real world are thus probably closer to the WW values than they are in the model. 
Fractionation during dissolution also affected the $\delta^{30} \mathrm{Si}$ of BSi exported from the ML, decreasing it by $0.2 \%$ during the bloom period but increasing it by $0.3 \%$ during winter (Fig. 8b). Despite this, it did not have a significant effect on the yearly average $\delta^{30} \mathrm{Si}$ of BSi exported from the ML. The annual average value of exported BSi was $+1.64 \%$ in the absence of fractionation during dissolution and $+1.65 \%$ with fractionation during dissolution, values that are both very close to the $+1.60 \%$ value of DSi input to the ML from WW (Fig. 8b).

The efficiency of BSi export (BSi exported divided by BSi produced) was not controlled in the model, but varied throughout the year due to changes in the mixed layer depth, $\mathrm{BSi}$ concentration, and the sinking velocity of the BSi. In reality, the controls on export efficiency are not well understood, but include the compositions and abundances of the phytoplankton and zooplankton communities, the food web structure, the episodic versus continuous nature of primary production, and concentrations of sticky exopolymers that enable the formation of large, rapidly sinking particles through aggregation. In short, it is likely that export efficiency varies considerably from one time of the year to another. Therefore, given the large annual range in the $\delta^{30} \mathrm{Si}$ of BSi (Fig. 6), the exact $\delta^{30} \mathrm{Si}$ of BSi exported and accumulating in the sediments must be strongly influenced by the variations in BSi export efficiency throughout the year. For example, if BSi produced during the spring bloom (representing maximal $\delta^{30} \mathrm{Si}$ values) is preferentially exported to sediments relative to BSi produced during other times of the year (representing lower $\delta^{30} \mathrm{Si}$ ), the sedimentary record of $\delta^{30} \mathrm{Si}$ will be higher than if winter BSi was preferentially exported, or if there was no variation in export efficiency throughout the year. This strongly implies that interpretation of paleoceanographic records of $\delta^{30} \mathrm{Si}$ would be improved by understanding the extent to which the sedimentary record serves as a yearly integrated signal or that biased towards one season or another.

Records of the diatom species composition of Southern Ocean sediments show that over time, different types of diatoms (produced at different times of the year) accumulate in the sediments. For example, in some cores from the Antarctic Polar Frontal Region, heavily silicified (and strongly resistant to dissolution) winter resting stages of Eucampia antarctica can represent half of the diatom frustules present at the Last Glacial Maximum (perhaps not coincidentally the time of lowest recorded $\delta^{30} \mathrm{Si}$ values (e.g. De La Rocha et al., 1998; Brzezinski et al., 2002)), while in other cores and at other times these winter stages are numerically never more than $10 \%$ of the diatom frustules present (Des Combes et al., 2008).

\subsubsection{Model runs including basalt weathering}

One set of simulations was run, both with and without fractionation during BSi dissolution, but with DSi input into the
ML from basalt weathering. This was done in two ways. In the first, or "constant basalt input" scenario, a small and constant amount of DSi from basalt was input directly to the ML at each time step to simulate input from weathering on Kerguelen and Heard islands and in shallower areas (seafloor $<250 \mathrm{mbsl}$ ) of the Kerguelen Plateau. Over the course of the year, this basalt input was equivalent to $10 \%$ of the total input from mixing, in accordance with Fripiat et al. (2011a). In the "variable basalt input scenario", the $\delta^{30} \mathrm{Si}$ of WW input to the ML was set to reflect a maximum of $10 \%$ contribution from basalt weathering at each time step and was therefore linked to the ML depth evolution.

Values for the $\delta^{30} \mathrm{Si}$ of the basalt DSi from $-1.0 \%$ to $+1.8 \%$ were tested, spanning most of the range of values known for DSi solutions produced during basalt weathering on land (Ziegler et al., 2005; Georg et al., 2007b; Pogge von Strandmann et al., 2012). For example, DSi with $\delta^{30} \mathrm{Si}$ values ranging from -1.1 to $+2.0 \%$ o have been reported for soil solutions and rivers associated with basalt weathering in Hawaii (Ziegler et al., 2005), while a range of values from $-0.08 \%$ o to $+1.51 \%$ o has been reported for DSi in Icelandic rivers, also a product of basalt weathering (Georg et al., 2007b).

Unfortunately, there have been no studies addressing the $\delta^{30} \mathrm{Si}$ of DSi produced during the submarine weathering of basalt. While inputs of Si from basalt weathering on the islands must certainly occur, given that only a small portion of the Kerguelen Plateau resides above sea level, it is likely that much of the basalt-derived DSi in the region is released during submarine weathering. Because a significant fraction of the Si released during submarine dissolution of basalt will become incorporated into clay minerals like smectite, it is inappropriate to use instead the average $\delta^{30} \mathrm{Si}$ of basalt of $-0.35 \%$. Isotope fractionation during clay formation will cause the $\delta^{30} \mathrm{Si}$ of the DSi that is released to seawater to be different than the basalt, just as is seen with the weathering of basalt on land.

Because the WW input to the ML in the model has a $\delta^{30} \mathrm{Si}$ of $+1.6 \%$ and the highest value tested for the basalt-derived DSi was $+1.8 \%$, the general effect of adding basalt-derived DSi at either a constant daily rate or a variable rate linked to changes in the ML depth was to lower the $\delta^{30} \mathrm{Si}$ of DSi and, consequently, of BSi in the ML (Fig. 9). Likewise, the lower the $\delta^{30} \mathrm{Si}$ of the basalt-derived DSi, the greater the diminishment of ML $\delta^{30} \mathrm{Si}$. Thus the hypothesis that basalt-derived DSi could be driving down the $\delta^{30} \mathrm{Si}$ of DSi in the ML on the Kerguelen Plateau is not contradicted by tests covering most of the range of possible $\delta^{30} \mathrm{Si}$ for basalt-derived DSi.

Although the lowering effect persisted throughout the year, the strongest diminishment in ML $\delta^{30} \mathrm{Si}$ occurred during the period of greatest net BSi production (spring), resulting in much lower annual maximum values of $\delta^{30} \mathrm{Si}$ for ML DSi (and subsequently BSi) than would have occurred otherwise (Fig. 9). Essentially, input of basalt-derived DSi with its low $\delta^{30} \mathrm{Si}$ values worked against the effects of fractionation 


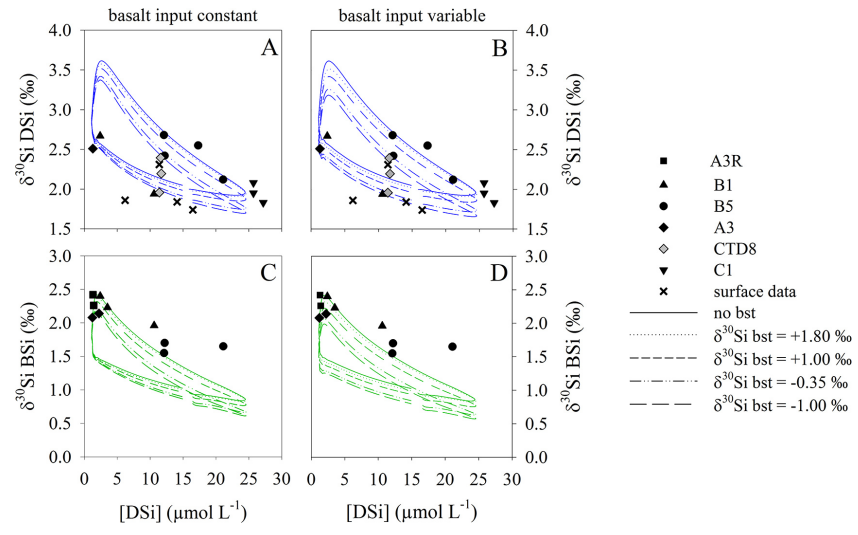

Fig. 9. Isotopic composition output versus DSi concentration for model runs with a constant basalt input (panels $\mathbf{A}$ and $\mathbf{C}$ ) and with a variable basalt input (panels $\mathbf{B}$ and $\mathbf{D}$ ). Panels (A) and (B) show $\delta^{30} \mathrm{Si}_{\mathrm{DSi}}$ and panels (C) and (D) show $\delta^{30} \mathrm{Si}_{\mathrm{BSi}}$. The surface data are from De La Rocha et al. (2011), stations A3R, B1, B5, A3, and $\mathrm{C} 1$ are from KEOPS (Fripiat et al., 2011b) and CTD8 is from this study.

during BSi production. In contrast, the effect of the basaltderived DSi was minor during the middle of summer when BSi production declined due to nutrient limitation and the ML values of $\delta^{30} \mathrm{Si}$ approached the $\delta^{30} \mathrm{Si}$ of the inputs as a whole.

Unfortunately, this modelling cannot be used to constrain the possible range of values for basalt-derived DSi on the Kerguelen Plateau. However, it is worth noting that when the $\delta^{30} \mathrm{Si}$ of basalt-derived DSi is set to $-1.0 \%$ o, the model output yields its best match with the $\delta^{30} \mathrm{Si}$ data from Kerguelen Plateau stations A3 and B1 (Fig. 9), which are the KEOPS campaign stations identified as best representing the plateau locality. Studies directly addressing the release and isotopic composition of DSi during basalt weathering (subaerial and submarine) on the Kerguelen Plateau are however necessary to confirm this.

\subsection{Sensitivity analysis}

The parameters that are important for the behaviour of the model in terms of the silicon concentration are the maximum diatom growth rate $\left(\mu_{\max }\right)$, the mortality rate of the diatoms, the dissolution rate of the $\mathrm{BSi}$, and the half-saturation constant $\left(K_{\mathrm{Si}}\right)$ for DSi uptake by the diatoms. In terms of directly affecting silicon isotopes, the $\delta^{30} \mathrm{Si}$ input to the mixed layer through mixing, and the fractionation factors for BSi production $\left(\varepsilon_{\text {prod }}\right)$ and dissolution $\left(\varepsilon_{\text {diss }}\right)$ are key.

We tested the sensitivity of the model to these different parameters by calculating a sensitivity index (SI), as follows:

$\mathrm{SI}=\frac{1}{t} \sum_{t=1}^{t=n} \frac{\left.\left(\sqrt{\left(X_{\mathrm{std}}-X_{\mathrm{var}}\right.}\right)^{2}\right)}{X_{\mathrm{std}}}$

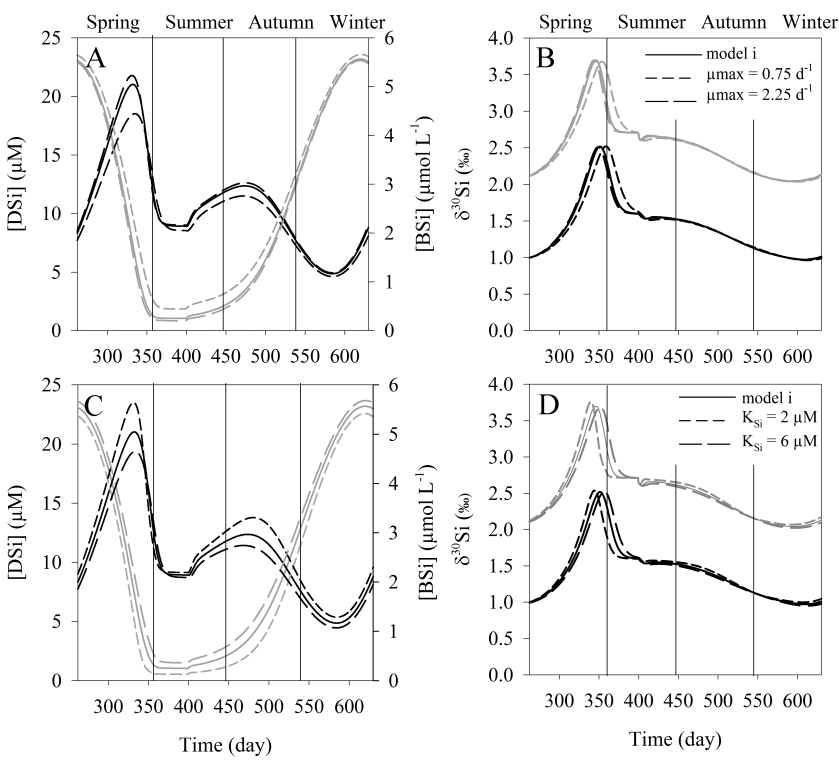

Fig. 10. (A) DSi and BSi concentrations with time for model runs with $\mu_{\max }$ values $\pm 50 \%$ of the initial value $\left(\mu_{\max }=1.5 \mathrm{~d}^{-1}\right),(\mathbf{C})$ DSi and BSi concentrations with time for model runs with $K_{\mathrm{Si}}$ values $\pm 50 \%$ of the initial value $\left(K_{\mathrm{Si}}=4 \mu \mathrm{mol}-\mathrm{Si}\right)$, and (B) and (D) $\delta^{30} \mathrm{Si}$ of DSi and BSi versus time for the model runs where $\mu_{\max }$ (B) and $K_{\mathrm{Si}}$ (D) were tested. Black: BSi, grey: DSi, solid line: initial run, dashed lines: values tested.

where $X_{\text {std }}$ is the initial model solution for the variable $X$ (DSi or BSi and concentration or $\delta^{30} \mathrm{Si}$ ), $X_{\mathrm{var}}$ is the model solution for a given variation, and $t$ is the time. The SI generally varies between zero and one, with values of one indicating a $100 \%$ change in the model output (Table 4 ).

The sensitivity was tested in one of two ways: by varying the parameters used in the initial modelling by $\pm 50 \%$ or by testing with values of interest taken from the literature.

The maximum growth rate $\left(\mu_{\max }\left(\mathrm{d}^{-1}\right)\right)$ was fixed in the initial modelling at $1.5 \mathrm{~d}^{-1}$ (solid line in Fig. 10a and b). Increasing this value by $50 \%$ had only a limited effect on concentrations of DSi and BSi throughout the year (Fig. 10a), with what effect there is to be seen (generally less than $1 \mu \mathrm{mol} \mathrm{L}^{-1}$ difference) confined to the summer (Table 4). Decreasing the value of $\mu_{\max }$ by $50 \%$ (Fig. 10a) drives a slightly larger change in the concentrations, up to about $2.5 \mu \mathrm{mol} \mathrm{L}-1$, with the largest effect again observed during summer. The SI values associated with these tests for $\mu_{\max } \pm 50 \%$ ranged from a low of 0.009 in the winter $-50 \%$ case to a high of 0.754 in the summer, again for the $-50 \%$ case (Table 4). In both cases, the timing and general pattern of DSi drawdown in spring and recovery in autumn and winter as well as peaks in BSi biomass in spring and autumn remain unchanged.

The effect on the $\delta^{30} \mathrm{Si}$ of DSi and BSi of changes to $\mu_{\max }$ is a change in the timing of the peak at the end of spring (Fig. 10b). The effect is really observable for a decrease in 
Table 4. Sensitivity index (SI) per season for coefficients tested; SI varies from $0(0 \%)$ to $1(100 \%)$.

\begin{tabular}{|c|c|c|c|c|c|c|}
\hline & & & Spring & Summer & Autumn & Winter \\
\hline \multirow{8}{*}{$\mu \max$} & \multirow{4}{*}{0.75} & [DSi] & 0.259 & 0.735 & 0.238 & 0.026 \\
\hline & & $\delta^{30} \mathrm{Si} \mathrm{DSi}$ & 0.032 & 0.036 & 0.002 & 0.005 \\
\hline & & [BSi] & 0.096 & 0.055 & 0.068 & 0.050 \\
\hline & & $\delta^{30} \mathrm{Si} \mathrm{BSi}$ & 0.044 & 0.059 & 0.004 & 0.011 \\
\hline & \multirow{4}{*}{2.25} & [DSi] & 0.069 & 0.178 & 0.067 & 0.009 \\
\hline & & $\delta^{30} \mathrm{Si} \mathrm{DSi}$ & 0.013 & 0.007 & 0.001 & 0.001 \\
\hline & & [BSi] & 0.032 & 0.014 & 0.021 & 0.017 \\
\hline & & $\delta^{30} \mathrm{Si} \mathrm{BSi}$ & 0.016 & 0.013 & 0.002 & 0.002 \\
\hline \multirow{8}{*}{$\mathrm{KSi}$} & \multirow{4}{*}{2} & [DSi] & 0.203 & 0.476 & 0.296 & 0.048 \\
\hline & & $\delta^{30} \mathrm{Si} \mathrm{DSi}$ & 0.041 & 0.019 & 0.012 & 0.003 \\
\hline & & [BSi] & 0.091 & 0.043 & 0.118 & 0.092 \\
\hline & & $\delta^{30} \mathrm{Si} \mathrm{BSi}$ & 0.046 & 0.041 & 0.021 & 0.006 \\
\hline & \multirow{4}{*}{6} & [DSi] & 0.177 & 0.449 & 0.223 & 0.035 \\
\hline & & $\delta^{30} \mathrm{Si} \mathrm{DSi}$ & 0.024 & 0.025 & 0.008 & 0.001 \\
\hline & & [BSi] & 0.067 & 0.038 & 0.082 & 0.073 \\
\hline & & $\delta^{30} \mathrm{Si} \mathrm{BSi}$ & 0.034 & 0.041 & 0.014 & 0.003 \\
\hline \multirow{8}{*}{ Mortality rate } & \multirow{4}{*}{0.096} & [DSi] & 0.314 & 0.291 & 0.245 & 0.092 \\
\hline & & $\delta^{30} \mathrm{Si} \mathrm{DSi}$ & 0.093 & 0.016 & 0.020 & 0.025 \\
\hline & & [BSi] & 0.294 & 0.175 & 0.279 & 0.422 \\
\hline & & $\delta^{30} \mathrm{Si} \mathrm{BSi}$ & 0.130 & 0.037 & 0.034 & 0.041 \\
\hline & \multirow{4}{*}{0.288} & [DSi] & 0.250 & 0.255 & 0.175 & 0.048 \\
\hline & & $\delta^{30} \mathrm{Si} \mathrm{DSi}$ & 0.049 & 0.024 & 0.012 & 0.012 \\
\hline & & [BSi] & 0.153 & 0.080 & 0.138 & 0.180 \\
\hline & & $\delta^{30} \mathrm{Si} \mathrm{BSi}$ & 0.071 & 0.040 & 0.020 & 0.016 \\
\hline \multirow{8}{*}{ Dissolution rate } & \multirow{4}{*}{0.023} & [DSi] & 0.011 & 0.004 & 0.007 & 0.005 \\
\hline & & $\delta^{30} \mathrm{Si} \mathrm{DSi}$ & 0.007 & 0.001 & 0.003 & 0.005 \\
\hline & & [BSi] & 0.006 & 0.001 & 0.003 & 0.013 \\
\hline & & $\delta^{30} \mathrm{Si} \mathrm{BSi}$ & 0.007 & 0.001 & 0.001 & 0.002 \\
\hline & \multirow{4}{*}{0.2} & [DSi] & 0.334 & 0.182 & 0.218 & 0.094 \\
\hline & & $\delta^{30} \mathrm{Si} \mathrm{DSi}$ & 0.129 & 0.036 & 0.068 & 0.068 \\
\hline & & [BSi] & 0.141 & 0.061 & 0.076 & 0.214 \\
\hline & & $\delta^{30} \mathrm{Si} \mathrm{BSi}$ & 0.126 & 0.032 & 0.052 & 0.048 \\
\hline \multirow{8}{*}{$\delta^{30} \mathrm{Si} \mathrm{WW}$} & \multirow{4}{*}{$1.4 \%$} & [DSi] & 0.000 & 0.000 & 0.000 & 0.000 \\
\hline & & $\delta^{30} \mathrm{Si} \mathrm{DSi}$ & 0.074 & 0.074 & 0.083 & 0.096 \\
\hline & & [BSi] & 0.000 & 0.000 & 0.000 & 0.000 \\
\hline & & $\delta^{30} \mathrm{Si} \mathrm{BSi}$ & 0.137 & 0.121 & 0.147 & 0.195 \\
\hline & \multirow{4}{*}{$1.8 \% 0$} & [DSi] & 0.000 & 0.000 & 0.000 & 0.000 \\
\hline & & $\delta^{30} \mathrm{Si} \mathrm{DSi}$ & 0.074 & 0.074 & 0.083 & 0.096 \\
\hline & & [BSi] & 0.000 & 0.000 & 0.000 & 0.000 \\
\hline & & $\delta^{30} \mathrm{Si} \mathrm{BSi}$ & 0.137 & 0.121 & 0.147 & 0.195 \\
\hline \multirow{8}{*}{ Fractionation } & \multirow{4}{*}{$\varepsilon_{\text {prod }}=-0.54$} & [DSi] & 0.000 & 0.000 & 0.000 & 0.000 \\
\hline & & $\delta^{30} \mathrm{Si} \mathrm{DSi}$ & 0.213 & 0.210 & 0.175 & 0.121 \\
\hline & & [BSi] & 0.000 & 0.000 & 0.000 & 0.000 \\
\hline & & $\delta^{30} \mathrm{Si} \mathrm{BSi}$ & 0.150 & 0.036 & 0.089 & 0.290 \\
\hline & \multirow{4}{*}{$\varepsilon_{\text {prod }}=-2.09$} & [DSi] & 0.000 & 0.000 & 0.000 & 0.000 \\
\hline & & $\delta^{30} \mathrm{Si} \mathrm{DSi}$ & 0.377 & 0.372 & 0.310 & 0.214 \\
\hline & & [BSi] & 0.000 & 0.000 & 0.000 & 0.000 \\
\hline & & $\delta^{30} \mathrm{Si} \mathrm{BSi}$ & 0.265 & 0.063 & 0.157 & 0.513 \\
\hline
\end{tabular}



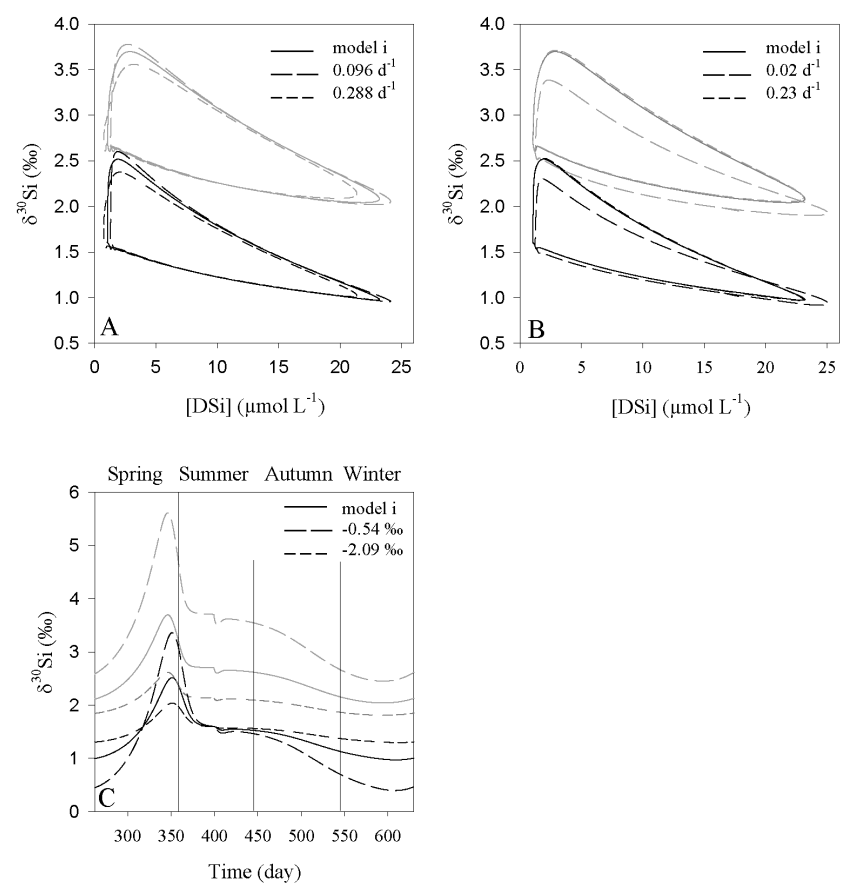

Fig. 11. Influence of the different (A) mortality rates on the $\delta^{30} \mathrm{Si}$ of DSi and BSi versus DSi concentration, $(\mathbf{B})$ dissolution rates on the $\delta^{30} \mathrm{Si}$ of DSi and BSi versus DSi concentration and $(\mathbf{C})$ variation of the $\delta^{30} \mathrm{Si}$ DSi and BSi versus time for different $\varepsilon_{\text {prod }}$. Black: BSi, grey: DSi, solid line: initial run, dashed lines: values tested.

$\mu_{\max }$ by $50 \%$, something which leads to a roughly 15 -day delay in the peaks of $\delta^{30} \mathrm{Si}$ in DSi and BSi. An increase of $50 \%$ has little effect (Table 4).

The half-saturation constant for silicon uptake $\left(K_{\mathrm{Si}}(\mu \mathrm{mol}-\right.$ $\left.\mathrm{Si}^{-1}\right)$ ) controls the affinity of diatoms for DSi uptake in the model and was initially fixed at $4 \mu \mathrm{mol}-\mathrm{Si} \mathrm{L}^{-1}$ (Fig. 10c and d), based on values from the literature. Decreasing $K_{\mathrm{Si}}$ to $2 \mu \mathrm{M}$ (the parameter minus $50 \%$ sensitivity test) allowed diatoms to take up DSi at maximal rates at lower DSi concentrations than when the $K_{\mathrm{Si}}$ was set to $6 \mu \mathrm{M}$ (the parameter plus $50 \%$ ). The result was, predictably, higher standing stocks of BSi during the spring and autumn blooms for the lower half-saturation constant, and lower standing stocks of BSi during the spring and autumn blooms for the higher half-saturation constant. Again, the overall effects are not huge, never more than about $3 \mu \mathrm{mol} \mathrm{L}-1$ relative to the runs with the initial $K_{\mathrm{Si}}$ value, and normally much less than this (Fig. 10c). In this case the maximal effect on DSi was 0.476 (SI) in summer at $K_{\mathrm{Si}}-50 \%$ (Table 4). For BSi, the maximum SI was 0.118 and in autumn. For $\delta^{30} \mathrm{Si}$, the impact is always less than $10 \%(\mathrm{SI}<0.082)$ (Table 4$)$. The $\delta^{30} \mathrm{Si}$ of DSi and BSi are sensitive to the variation in $K_{\mathrm{Si}}$ to a similar extent (Fig. 10d). A decrease of $50 \%$ of $K_{\mathrm{Si}}(2 \mu \mathrm{M})$ leads to an earlier increase in the $\delta^{30} \mathrm{Si}$ for both DSi and BSi. An increase for $K_{\mathrm{Si}}$ of $6 \mu \mathrm{M}$ had the opposite effect and to a similar extent, with maximal values of $\delta^{30} \mathrm{Si}$ observed slightly later.

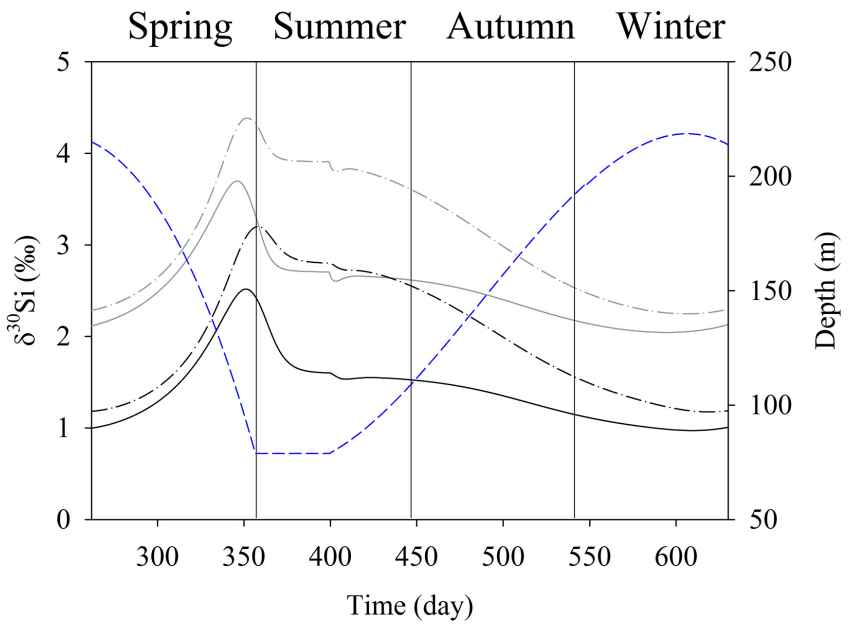

Fig. 12. Evolution of $\delta^{30} \mathrm{Si}$ for DSi (grey lines) and BSi (black lines) versus time for the initial model run (solid lines) and for the model run where $\delta^{30} \mathrm{Si}_{\mathrm{WW}}$ is allowed to vary with the ML depth (blue dashed lines).

The mortality rate is another important parameter in the model, especially because it is linked to dissolution in that only dead diatoms are allowed to dissolve. The sensitivity of the model to this parameter was also tested for values $\pm 50 \%$ of the initially assigned value of $0.192 \mathrm{~d}^{-1}$. In Table 4 we can see that the mortality influences both DSi concentration and the $\delta^{30} \mathrm{Si}$ of both BSi and DSi mainly at the lowest and highest DSi concentrations. It affects BSi concentrations also (Fig. 11a). These two periods of greatest influence correspond to the ends of winter and summer. A $50 \%$ increase in the mortality rate leads to higher values of the $\delta^{30} \mathrm{Si}$ of DSi and BSi just before the end of summer (i.e. just before DSi concentrations cease decreasing) as well as slightly higher minimal values of DSi concentration in late summer and a higher peak concentration of DSi in the mixed layer in winter. A smaller range of DSi concentrations and $\delta^{30} \mathrm{Si}$ values is observed for a $50 \%$ decrease in mortality rate.

To test the sensitivity of the model to the dissolution rate, instead of using values $\pm 50 \%$ of the value ultimately used in the modelling, specific values were selected from the literature. At the upper extreme, a dissolution rate of $0.23 \mathrm{~d}^{-1}$ was used corresponding to the estimated average BSi dissolution rate in the surface ocean (Van Cappellen et al., 2002). For the model it represents a variation of $+657 \%$. At the lower extreme, a dissolution rate of $0.02 \mathrm{~d}^{-1}$ was used, representing the average dissolution rate in the Antarctic Circumpolar Current (Van Cappellen et al., 2002) and equalling a value equal to $57 \%$ of that ultimately used in the modelling. Decreasing the dissolution rate ( $\left.T_{\text {diss }}\right)$ to $0.02 \mathrm{~d}^{-1}$ had virtually no impact; the results are essentially identical to the "normal" run (Fig. 11b), suggesting that minimal dissolution occurs in the "normal" run of the model. Use of the higher value of $0.23 \mathrm{~d}^{-1}$ has, however, a significant effect, resulting in an 

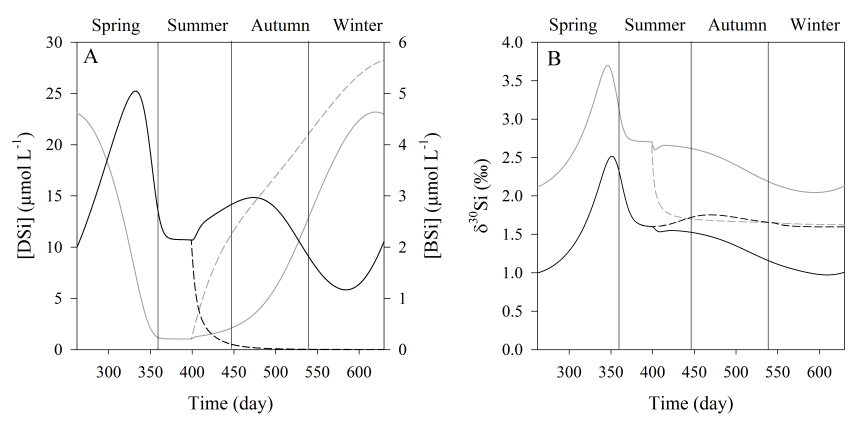

Fig. 13. Model run with no post-bloom BSi production. (A) DSi and $\mathrm{BSi}$ concentrations and (B) the $\delta^{30} \mathrm{Si}$ of DSi and BSi. BSi is black, DSi is grey. The solid line represents the initial run and dotted lines represent the run where BSi production is halted at the end of net nutrient drawdown.

increase in the DSi concentration as well as a decrease in the range of $\delta^{30} \mathrm{Si}$ for both DSi and $\mathrm{BSi}$. This behaviour is expected because dissolution will increase the amount of $\mathrm{BSi}$ dissolved and because dissolution enriches the DSi with the lighter isotope $\left({ }^{28} \mathrm{Si}\right)$ due to the lower $\delta^{30} \mathrm{Si}$ value of the $\mathrm{BSi}$ compared to the DSi in the ML.

In the model, we used a fractionation of $-1.1 \%$ o during BSi production, as it is the average value observed for diatoms in culture (De La Rocha et al., 1997), in low-latitude upwelling zones (De La Rocha et al., 2000), and very close to the average value determined for diatoms in the Antarctic Circumpolar Current (Fripiat et al., 2011b). However, although initial reports suggested that this fractionation factor was relatively invariant from species to species, according to Sutton et al. (2013) the fractionation during BSi production is in fact species dependent, varying from at least $-0.54 \%$ o for Fragilariopsis kerguelensis up to $-2.09 \%$ for Chaetoceros brevis, both of which are Southern Ocean diatoms. For that reason we decided to test these two values in our model sensitivity tests (Fig. 11c). An increase in the extent of the discrimination against the heavier isotope (the $\varepsilon_{\text {prod }}$ of $-2.09 \%$ ) resulted in a significantly higher spring bloom maximum in $\delta^{30} \mathrm{Si}$ in both DSi and BSi (Fig. 11c). Likewise, the use of the lesser fractionation (the $\varepsilon_{\text {prod }}$ of $-0.54 \%$ ) resulted in significantly diminished spring bloom maxima in $\delta^{30} \mathrm{Si}$ and a much lesser and much less variable difference between the $\delta^{30} \mathrm{Si}$ of DSi and BSi throughout the year (Table 4).

The shift in diatom community composition during the spring bloom on the Kerguelen Plateau (e.g. as reported by Armand et al., 2008) could be influencing the $\delta^{30} \mathrm{Si}$ of DSi and BSi. Succession from Chaetoceros brevis to Eucampia antarctica has been observed and these species may fractionate silicon isotopes to differing degrees (e.g. $\varepsilon_{\text {prod }}$ is the unusually strong $-2.09 \%$ for Chaetoceros brevis (Sutton et al., 2003) compared to values closer to $-1 \%$ o for many other diatom species). Further modelling efforts might take into account variation of the fractionation factor associated with the probable pattern of succession. First, however, it would be useful to quantify isotope fractionation for all the main diatom species of the spring bloom in this region.

The choice of the constant value for the $\delta^{30} \mathrm{Si}$ mixed into the ML was set at the Winter Water value of $1.6 \%$. To see the influence of this value, two runs were undertaken where this $\delta^{30} \mathrm{Si}$ was instead set at $1.4 \%$ or $1.8 \% \circ( \pm 12.5 \%$ of the initial value). The resulting effects were to shift the $\delta^{30} \mathrm{Si}$ values (for BSi and DSi) versus DSi up or down by a few tenths of a permil. As expected, there was no influence on the DSi or BSi concentration (Table 4).

\subsubsection{Model behaviour for a varying Winter Water $\delta^{30} \mathbf{S i}$}

To evaluate how changes in the $\delta^{30} \mathrm{Si}$ of the mixing source can influence the predictions of $\delta^{30} \mathrm{Si}$ in the dissolved and particulate silicon pools in the mixed layer, we decided to test a varying $\delta^{30} \mathrm{Si}$ input related to changes in the depth of the mixed layer throughout the year (Fig. 12).

In our box model, the depth of the boundary between the surface mixed layer and the deep reservoir changes seasonally. In consequence, both the DSi concentration and the $\delta^{30} \mathrm{Si}$ in the source water below this boundary ( $\mathrm{DSi}_{0}$ and $\left.\delta^{30} \mathrm{Si}_{\mathrm{ww}}\right)$ are expected to change seasonally as well. However, in the initial model simulation, only $\mathrm{DSi}_{0}$ changes seasonally (see Sect. 2.2.1).

To estimate how $\delta^{30} \mathrm{Si}_{\mathrm{WW}}$ (the $\delta^{30} \mathrm{Si}$ of the mixing input) might change seasonally, the value was calculated as:

$\delta^{30} \mathrm{Siww}=7.077343-0.4867$

$\times[\mathrm{DSi}]_{\mathrm{WW}}+0.0156 \times[\mathrm{DSi}]_{\mathrm{WW}}^{2}-0.0002 \times[\mathrm{DSi}]_{\mathrm{WW}}^{3}$.

In this equation, the lowest $\delta^{30} \mathrm{Si}(1.6 \%$ ) is assigned to the highest DSi concentration (representing true WW mixed in at the time when the ML is deepest). The maximal $\delta^{30} \mathrm{Si}$ $(2.58 \%$ ) is tied to the lowest DSi concentration, which is the input at the time when the upper water column is most stratified and the ML is the shallowest. This improvement in the model leads to $\delta^{30} \mathrm{Si}_{\mathrm{Ww}}$ that varies from $1.58 \%$ when the ML is the deepest (and the DSi input comes from the true WW present at the deepest depth of winter mixing) up to values up to $2.80 \%$ at the shallowest ML depth when the water directly below the thermocline is a relic of the ML at the previous time step.

Run this way, the model yields values of $\delta^{30} \mathrm{Si}$ for DSi and BSi that are higher during most of the year than in the initial (constant $\delta^{30} \mathrm{Si}_{\mathrm{WW}}$ ) run. The overall trend is the same for the $\delta^{30} \mathrm{Si}$ evolution, but the major difference is visible from the end of spring until winter, when the initial decrease in the $\delta^{30} \mathrm{Si}$ at the end of the bloom is less sharp for both DSi and $\mathrm{BSi}$. Another thing to note is that the peak for both DSi and $\mathrm{BSi}$ in the new version of the model is almost $0.6 \%$ higher. As explained above, in the new run the $\delta^{30} \mathrm{Si}_{\mathrm{WW}}$ increases from 1.58 to $2.80 \%$ as the ML shoals, and this acts to increase the ML $\delta^{30} \mathrm{Si}$ at some times of the year. The slower 
decrease in ML $\delta^{30} \mathrm{Si}$ as the ML deepens is due to the same processes, but in reverse (as the ML deepens, the $\delta^{30} \mathrm{Si}_{\mathrm{WW}}$ decreases towards the true WW value).

Although allowing $\delta^{30} \mathrm{Si}_{\mathrm{WW}}$ to vary like this is more realistic than holding it to a constant value, the KEOPS data from Fripiat et al. (2011b) make a better match with the results when the model is run holding $\delta^{30} \mathrm{Si}$ ww constant. This may suggest that on the Kerguelen Plateau, DSi from the WW at the deepest depth of winter mixing of the surface layer plays a strong role as a source of DSi to the ML even in late spring and summer. However, the significant differences between the two model runs highlight the importance of considering seasonal variations in both the DSi concentration and its $\delta^{30} \mathrm{Si}$ being mixed into the ML, even when working with something as simple as a box model.

\subsubsection{Behaviour of the model when BSi production in winter is prohibited}

To demonstrate the effect of the low levels of BSi production that occur during non-bloom periods of the year (i.e. times of no net decrease in the DSi concentration of the ML) in the model (Sect. 3.2.3), a simulation was performed with BSi production set to zero starting from the time that net drawdown of DSi concentrations ceased at the beginning of summer (Fig. 13).

When BSi production ceased, DSi concentrations increased and the BSi concentration moved quickly towards zero (Fig. 13a). In turn, $\delta^{30} \mathrm{Si}_{\mathrm{DSi}}$ declined, converging towards the $\delta^{30} \mathrm{Si}$ value of the input WW (1.6\%) still being added to it (Fig. 13b). The $\delta^{30} \mathrm{Si}_{B S i}$ remaining in the ML showed a slight increase as the dissolution and sinking of "dead" BSi (and continuing mortality of the "live" BSi) diminished the amount of BSi in the ML. All told, the model reacted in an expected way to the cessation of BSi production during the "non-bloom" period, underscoring the point that BSi production does indeed continue throughout the seemingly "non-productive" times of the year, just at rates equal to or lower than those of DSi input to the ML.

\section{Conclusions}

The results from the variable mixed layer depth model of silica and silicon isotope cycling presented here offer insight into the behaviour of silicon isotopes in the general vicinity of the Kerguelen Plateau and, more importantly, into the interpretation of marine silicon isotope data in general. For example, the model illustrated that the decline in $\delta^{30} \mathrm{Si}$ of DSi observed between summer and early autumn in this area, decoupled from notable change in DSi concentrations (De La Rocha et al., 2011; Fripiat et al., 2011b), could be ascribed to a shift from bloom-dominated growth (BSi production by diatoms vastly outpacing DSi supply to the ML via mixing) to steady state growth (BSi production by diatoms keeping almost perfect pace with the supply of DSi to the ML via diffusion). Such a decrease in $\delta^{30} \mathrm{Si}$ of ML DSi is likely to occur (without notable net change in DSi concentrations) with the stratification that follows the seasonal phytoplankton bloom in coastal margins, upwelling zones, and in general any locality featuring episodic phytoplankton blooms. This may in turn suggest that the $\delta^{30} \mathrm{Si}$ of diatom silica as a paleoceanographic proxy (De La Rocha et al., 1998; Brzezinski et al., 2002; Crosta et al., 2007) may more strongly reflect the dominant mode of production (higher $\delta^{30} \mathrm{Si}=$ bloom growth, lower $\delta^{30} \mathrm{Si}=$ steady state growth) rather than reflect the extent of removal of DSi for BSi production.

Fractionation during the dissolution of BSi had a visible effect in the model, lowering the $\delta^{30} \mathrm{Si}$ of DSi in the ML by about $0.2 \%$ throughout the duration of the year, and diminishing the yearly range of $\delta^{30} \mathrm{Si}$ of $\mathrm{BSi}$ (by reducing the maximum $\delta^{30}$ Si value attained at the peak of bloom growth), also by roughly $0.2 \%$. In this case for the Kerguelen Plateau, this represented a $13 \%$ reduction in the amplitude of the seasonal $\delta^{30} \mathrm{Si}$ signal in BSi in the water column. However, fractionation during dissolution has a negligible effect on the annual average $\delta^{30} \mathrm{Si}$ of $\mathrm{BSi}$ exported from the mixed layer. Nevertheless, if only the bloom silica accumulates in the sediments, the extent of the DSi removal associated with the bloom would be underestimated because of the overall decrease in the $\delta^{30} \mathrm{Si}$ of ML DSi and the potential damping of the full seasonal signal in the $\delta^{30} \mathrm{Si}$ of BSi due to fractionation during dissolution. Thus the effects of fractionation during dissolution may need to be considered for correct interpretation of paleoceanographic reconstructions based on $\delta^{30} \mathrm{Si}$. However, even without fractionation during dissolution, season variations in BSi export efficiency should have a significant impact on the $\delta^{30} \mathrm{Si}$ of BSi accumulating in sediments.

The model results also suggest that the input of DSi from basalt weathering on the Kerguelen Plateau could have a significant influence over ML $\delta^{30} \mathrm{Si}$, provided that the $\delta^{30} \mathrm{Si}$ of this released DSi is low enough relative to that of waters mixing into the ML. However, this topic requires direct investigation of the amount and isotopic composition of DSi added by this process, as the isotopic composition is not necessarily directly equivalent to that of the basalt (weathering involves processes of dissolution as well as the formation of Si-containing secondary minerals).

Finally, the model run tested with $\delta^{30} \mathrm{Si}$ ww allowed to vary throughout the year suggests that it is important to consider seasonal variations in the $\delta^{30} \mathrm{Si}$ input to the ML as the upper ocean stratifies, cutting the ML off from the deeper sources of DSi tapped during winter mixing. 
Acknowledgements. We thank E. Ponzevera and Y. Germain for technical support and two anonymous reviewers for comments. This work was supported by LEFE/CYBER grants SiMS and SiBRED to CDLR and by student funding from Region Bretagne.

Edited by: A. Shemesh

\section{References}

Abraham, K., Opfergelt, S., Fripiat, F., Cavagna, A.-J., De Jong, J. T. M., Foley, S. F., André, L., and Cardinal, D.: $\delta^{30} \mathrm{Si}$ and $\delta^{29} \mathrm{Si}$ determinations on USGS BHVO-1 and BHVO-2 reference materials with a new configuration on a Nu Plasma Multi-Collector ICP-MS, Geostand. Geoanal. Res., 32, 193-202, 2008.

Alldredge, A. L., and Gotschalk, C.: In situ settling behavior of marine snow, DTIC Document, 1988.

Bern, C. R., Brzezinski, M. A., Beucher, C., Ziegler, K., and Chadwick, O. A.: Weathering, dust, and biocycling effects on soil silicon isotope ratios, Geochim. Cosmochim. Acta., 74, 876-889, 2010.

Beucher, C., Tréguer, P., Hapette, A.-M., Corvaisier, R., Metzl, N., and Pichon, J.-J.: Intense summer Si-recycling in the surface Southern Ocean, Geophys. Res. Lett., 31, L09305, doi:10.1029/2003g1018998, 2004.

Beucher, C. P., Brzezinski, M. A., and Jones, J. L.: Sources and biological fractionation of silicon isotopes in the Eastern Equatorial Pacific, Geochim. Cosmochim. Acta, 72, 3063-3073, 2008.

Beucher, C. P., Brzezinski, M. A., and Jones, J. L.: Mechanisms controlling silicon isotope distribution in the Eastern Equatorial Pacific, Geochim. Cosmochim. Acta, 75, 4286-4294, 2011.

Blain, S., Queguiner, B., Armand, L., Belviso, S., Bombled, B., Bopp, L., Bowie, A., Brunet, C., Brussaard, C., Carlotti, F., Christaki, U., Corbiere, A., Durand, I., Ebersbach, F., Fuda, J.L., Garcia, N., Gerringa, L., Griffiths, B., Guigue, C., Guillerm, C., Jacquet, S., Jeandel, C., Laan, P., Lefevre, D., Lo Monaco, C., Malits, A., Mosseri, J., Obernosterer, I., Park, Y.-H., Picheral, M., Pondaven, P., Remenyi, T., Sandroni, V., Sarthou, G., Savoye, N., Scouarnec, L., Souhaut, M., Thuiller, D., Timmermans, K., Trull, T., Uitz, J., van Beek, P., Veldhuis, M., Vincent, D., Viollier, E., Vong, L., and Wagener, T.: Effect of natural iron fertilization on carbon sequestration in the Southern Ocean, Nature, 446, 10701074, 2007.

Brzezinski, M. A. and Nelson, D. M.: Chronic substrate limitation of silicic acid uptake rates in the western Sargasso Sea, Deep-Sea Res. II, 43, 437-453, 1996.

Brzezinski, M. A., Nelson, D. M., Franck, V. M., and Sigmon, D. E.: Silicon dynamics within an intense open-ocean diatom bloom in the Pacific sector of the Southern Ocean, Deep-Sea Res. II, 48, 3997-4018, 2001.

Brzezinski, M. A., Pride, C. J., Franck, V. M., Sigman, D. M., Sarmiento, J. L., Matsumoto, K., Gruber, N., Rau, G. H., and Coale, K. H.: A switch from $\mathrm{Si}(\mathrm{OH})_{4}$ to $\mathrm{NO}_{3}$ depletion in the glacial Southern Ocean, Geophys. Res. Lett., 29, 12, doi:10.1029/2001GL014349, 2002.

Cardinal, D., Alleman, L. Y., de Jong, J., Ziegler, K., and Andre, L.: Isotopic composition of silicon measured by multicollector plasma source mass spectrometry in dry plasma mode, J. Anal. Atom. Spectrom., 18, 213-218, 2003.
Cardinal, D., Alleman, L. Y., Dehairs, F., Savoye, N., Trull, T. W., and Andre, L.: Relevance of silicon isotopes to Si-nutrient utilization and Si-source assessment in Antarctic waters, Global Biogeochem. Cy., 19, GB2007, doi:10.1029/2004GB002364, 2005.

Cardinal, D., Savoye, N., Trull, T. W., Dehairs, F., Kopczynska, E. E., Fripiat, F., Tison, J.-L., and André, L.: Silicon isotopes in spring Southern Ocean diatoms: Large zonal changes despite homogeneity among size fractions, Mar. Chem., 106, 46-62, 2007.

Chan, A. T.: Comparative physiological study of marine diatoms and dinoflagellates in relation to irradiance and cellsize. 2. Relationship between photosynthesis, growth, and carbon:chlorophyll a ratio., J. Phycol., 16, 428-432, 1980.

Crosta, X., Beucher, C., Pahnke, K., and Brzezinski, M. A.: Silicic acid leakage from the Southern Ocean: Opposing effects of nutrient uptake and oceanic circulation, Geophys. Res. Lett., 34, L13601, doi:10.1029/2006GL029083, 2007.

Cunningham, C. M.: Southern Ocean circulation, Arch. Nat. Hist., 32, 265-280, 2005.

Dafner, E. V. and Mordasova, N. V.: Influence of biotic factors on the hydrochemical structure of surface water in the Polar Frontal Zone of the Atlantic Antarctic, Mar. Chem., 45, 137-148, 1994.

de Brauwere, A., Fripiat, F., Cardinal, D., Cavagna, A.-J., De Ridder, F., André, L., and Elskens, M.: Isotopic model of oceanic silicon cycling: The Kerguelen Plateau case study, Deep-Sea Res. I, 70, 42-59, 2012.

De La Rocha, C. L., Brzezinski, M. A., and DeNiro, M. J.: Purification, recovery, and laser-driven fluorination of silicon from dissolved and particulate silica for the measurement of natural stable isotope abundances, Anal. Chem., 68, 3746-3750, 1996.

De La Rocha, C. L., Brzezinski, M. A., and DeNiro, M. J.: Fractionation of silicon isotopes by marine diatoms during biogenic silica formation, Geochim. Cosmochim. Acta, 61, 5051-5056, 1997.

De La Rocha, C. L., Brzezinski, M. A., DeNiro, M. J., and Shemesh, A.: Silicon-isotope composition of diatoms as an indicator of past oceanic change, Nature, 395, 680-683, 1998.

De La Rocha, C. L., Brzezinski, A., and DeNiro, M. J.: A first look at the distribution of the stable isotopes of silicon in natural waters, Geochim. Cosmochim. Acta., 64, 2467-2477, 2000.

De La Rocha, C. L., Bescont, P., Croguennoc, A., and Ponzevera, E.: The silicon isotopic composition of surface waters in the Atlantic and Indian sectors of the Southern Ocean, Geochim. Cosmochim. Acta., 75, 5283-5295, 2011.

Demarest, M. S., Brzezinski, M. A., and Beucher, C. P.: Fractionation of silicon isotopes during biogenic silica dissolution, Geochim. Cosmochim. Acta., 73, 5572-5583, 2009.

de Souza, G. F., Reynolds, B. C., Johnson, G. C., Bullister, J. L., and Bourdon, B.: Silicon stable isotope distribution traces Southern Ocean export of Si to the eastern South Pacific thermocline, Biogeosciences, 9, 4199-4213, doi:10.5194/bg-9-41992012, 2012a.

de Souza, G. F., Reynolds, B. C., Rickli, J., Frank, M., Saito, M. A., Gerringa, L. J. A., and Bourdon, B.: Southern Ocean control of silicon stable isotope distribution in the deep Atlantic Ocean, Global Biogeochem. Cy., 26, GB2035, doi:10.1029/2011gb004141, 2012b.

Ding, T., Tang, L., Wan, D., Li, Y., Li, J., Song, H., Liu, Z., and Yao, X.: Silicon isotope geochemistry, Geological Publishing House, Beijing, China, 125 pp., 1996. 
Douthitt, C. B.: The geochemistry of the stable isotopes of silicon, Geochim. Cosmochim. Acta., 46, 1449-1458, 1982.

Engström, E., Rodushkin, I., Baxter, D. C., and Öhlander, B.: Chromatographic purification for the determination of dissolved silicon isotopic compositions in natural waters by high-resolution multicollector inductively coupled plasma mass spectrometry, Anal. Chem., 78, 250-257, 2006.

Evans, G. T. and Parslow, J. S.: A model of annual plankton cycles, Biol. Oceanogr., 3, 327-347, 1985.

Fasham, M. J. R., Ducklow, H. W., and McKelvie, S. M.: A nitrogen-based model of plankton dynamics in the oceanic mixed layer, J. Mar. Res., 48, 591-639, 1990.

Fasham, M. J. R., Flynn, K. J., Pondaven, P., Anderson, T. R., and Boyd, P. W.: Development of a robust marine ecosystem model to predict the role of iron in biogeochemical cycles: A comparison of results for iron-replete and iron-limited areas, and the SOIREE iron-enrichment experiment, Deep-Sea Res. I, 53, 333366, 2006.

Fripiat, F., Cavagna, A. J., Dehairs, F., Speich, S., Andre, L., and Cardinal, D.: Silicon pool dynamics and biogenic silica export in the Southern Ocean inferred from Si-isotopes, Ocean Sci., 7, 533-547, 2011a, http://www.ocean-sci.net/7/533/2011/.

Fripiat, F., Cavagna, A. J., Savoye, N., Dehairs, F., André, L., and Cardinal, D.: Isotopic constraints on the Si-biogeochemical cycle of the Antarctic Zone in the Kerguelen area (KEOPS), Mar. Chem., 123, 11-22, 2011 b.

Fripiat, F., Leblanc, K., Elskens, M., Cavagna, A. J., Armand, L., Andre, L., Dehairs, F., and Cardinal, D.: Efficient silicon recycling in summer in both the Polar Frontal and Subantarctic Zones of the Southern Ocean, Mar. Ecol. Prog. Ser., 435, 47-61, 2011c.

Fripiat, F., Cavagna, A.-J., Dehairs, F., de Brauwere, A., André, L., and Cardinal, D.: Processes controlling the Si-isotopic composition in the Southern Ocean and application for paleoceanography, Biogeosciences, 9, 2443-2457, doi:10.5194/bg-9-24432012, 2012.

Georg, R. B., Halliday, A. N., Schauble, E. A., and Reynolds, B. C.: Silicon in the Earth's core, Nature, 447, 1102-1106, 2007a.

Georg, R. B., Reynolds, B. C., West, A. J., Burton, K. W., and Halliday, A. N.: Silicon isotope variations accompanying basalt weathering in Iceland, Earth Planet. Sci. Lett., 261, 476-490, $2007 b$.

Jacot Des Combes, H., Esper, O., De La Rocha, C. L., Abelmann, A., Gersonde, R., Yam, R., and Shemesh, A.: Diatom $\delta^{13} \mathrm{C}, \delta^{15} \mathrm{~N}$, and $\mathrm{C} / \mathrm{N}$ since the Last Glacial Maximum in the Southern Ocean: Potential impact of species composition, $\mathrm{Pa}-$ leoceanography, 23, PA4209, doi:10.1029/2008PA001589, 2008.

Jacques, G.: Some ecophysiological aspects of the Antarctic phytoplankton, Polar Biol., 2, 27-33, 1983.

Jeandel, C., Ruiz-Pino, D., Gjata, E., Poisson, A., Brunet, C., Charriaud, E., Dehairs, F., Delille, D., Fiala, M., Fravalo, C., Miquel, J. C., Park, Y. H., Pondaven, P., Quéguiner, B., Razouls, S., Shauer, B., and Tréguer, P.: KERFIX, a time-series station in the Southern Ocean: a presentation, J. Mar. Syst., 17, 555-569, 1998. Jeandel, C., Peucker-Ehrenbrink, B., Jones, M. T., Pearce, C. R., Oelkers, E. H., Godderis, Lacan, F., Aumont, O., and Arsouze, T.: Ocean margins: The missing term in oceanic element budgets?, Trans. Am. Geophys. Union, 92, 217-218, 2011.
McCartney, M. S. and Donohue, K. A.: A deep cyclonic gyre in the Australian-Antarctic Basin, Prog. Oceanogr., 75, 675-750, 2007.

Milligan, A. J., Varela, D. E., Brzezinski, M. A., and Morel, F. M. M.: Dynamics of silicon metabolism and silicon isotopic discrimination in a marine diatom as a function of $p \mathrm{CO}_{2}$, Limnol. Oceanogr., 49, 322-329, 2004.

Mongin, M., Molina, E., and Trull, T. W.: Seasonality and scale of the Kerguelen plateau phytoplankton bloom: A remote sensing and modeling analysis of the influence of natural iron fertilization in the Southern Ocean, Deep-Sea Res. II, 55, 880-892, 2008.

Nelson, D. M. and Gordon, L. I.: Production and pelagic dissolution of biogenic silica in the Southern Ocean, Geochim. Cosmochim. Acta., 46, 491-501, 1982.

Nelson, D. M. and Smith, W. O.: Sverdrup revisited : critical depths, maximum chlorophyll levels, and the control of Southern Ocean productivity by the irradiance-mixing regime, Limnol. Oceanogr., 36, 1650-1661, 1991.

Nugraha, A., Pondaven, P., and Tréguer, P.: Influence of consumerdriven nutrient recycling on primary production and the distribution of $\mathrm{N}$ and $\mathrm{P}$ in the ocean, Biogeosciences, 7, 1285-1305, doi:10.5194/bg-7-1285-2010, 2010.

Oelkers, E. H., Gislason, S. R., Eiriksdottir, E. S., Jones, M. T., Pearce, C. R., and Jeandel, C.: The role of riverine particulate material on the global cycles of the elements, Appl. Geochem., 26, 365-369, 2011.

Opfergelt, S. and Delmelle, P.: Silicon isotopes and continental weathering processes: Assessing controls on Si transfer to the ocean, C. R. Geosci., 344, 723-738, 2012.

Orsi, A. H., Whitworth III, T., and Nowlin Jr, W. D.: On the meridional extent and fronts of the Antarctic Circumpolar Current, Deep-Sea Res. I, 42, 641-673, 1995.

Paasche, E.: Silicon and the ecology of marine plankton diatoms, II. Silicate-uptake kinetics in five diatom species, Mar. Biol., 19, 262-269, 1973.

Park, Y.-H., Gamberoni, L., and Charriaud, E.: Frontal structure, water masses, and circulation in the Crozet Basin, J. Geophys. Res-Oceans, 98, 12361-12385, 1993.

Park, Y.-H., Charriaud, E., and Fieux, M.: Thermohaline structure of the Antarctic Surface Water/Winter Water in the Indian sector of the Southern Ocean, J. Mar. Syst., 17, 5-23, 1998a.

Park, Y.-H., Roquet, F., Durand, I., and Fuda, J.-L.: Large-scale circulation over and around the Northern Kerguelen Plateau, DeepSea Res. II, 55, 566-581, 1998 b.

Park, Y.-H., Fuda, J.-L., Durand, I., and Naveira Garabato, A. C.: Internal tides and vertical mixing over the Kerguelen Plateau, Deep-Sea Res. II, 582-593, 2008.

Platt, T. and Jassby, A. D.: The relationship between photosynthesis and light for natural assemblages of coastal marine phytoplankton, J. Phycol., 12, 421-430, 1976.

Platt, T., Sathyendranath, S., Edwards, A. M., Broomhead, D. S., and Ulloa, O.: Nitrate supply and demand in the mixed layer of the ocean, Mar. Ecol. Prog. Ser., 254, 3-9, 2003.

Pogge von Strandmann, P. A. E., Opfergelt, S., Lai, Y.-J., Sigfússon, B., Gislason, S. R., and Burton, K. W.: Lithium, magnesium and silicon isotope behaviour accompanying weathering in a basaltic soil and pore water profile in Iceland, Earth Planet. Sci. Lett., 339/340, 11-23, 2012. 
Pondaven, P., Fravalo, C., Ruiz-Pino, D., Tréguer, P., Quéguiner, B., and Jeandel, C.: Modelling the silica pump in the Permanently Open Ocean Zone of the Southern Ocean, J. Mar. Syst., 17, 587619, 1998.

Roquet, F., Park, Y.-H., Guinet, C., Bailleul, F., and Charrassin, J.B.: Observations of the Fawn Trough Current over the Kerguelen Plateau from instrumented elephant seals, J. Mar. Syst., 78, 377393, 2009.

Sarthou, G., Timmermans, K. R., Blain, S., and Tréguer, P.: Growth physiology and fate of diatoms in the ocean: a review, J. Sea Res., 53, 25-42, 2005.

Savage, P. S., Georg, R. B., Williams, H. M., Burton, K. W., and Halliday, A. N.: Silicon isotope fractionation during magmatic differentiation, Geochim. Cosmochim. Acta, 75, 61246139, 2011.

Smayda, T. J.: The suspension and sinking of phytoplankton in the sea, Oceanogr. Mar. Biol. Ann. Rev., 8, 353-414, 1970.

Sommer, U.: Nitrate- and silicate-competition among antarctic phytoplankton, Mar. Biol., 91, 345-351, 1986.

Steele, J. H. and Henderson, E. W.: Predation control of plankton demography, ICES J. Mar. Sci., 52, 565-573, 1995.
Strickland, J. D. H. and Parsons, T. R.: A practical handbook of seawater analysis, Fish. Res. Board Can., Ottawa, 310 pp., 1972.

Sutton, J. N., Varela, D. E., Brzezinski, M. A., and Beucher, C. P.: Species-dependent silicon isotope fractionation by marine diatoms, Geochim. Cosmochim. Acta, 104, 300-309, 2013.

Tréguer, P. J. and De La Rocha, C. L.: The World Ocean Silica Cycle, Ann. Rev. Mar. Sci., 5, 477-501, 2013.

Tyrrell, T.: The relative influences of nitrogen and phosphorus on oceanic primary production, Nature, 400, 525-531, 1999.

Van Cappellen, P., Dixit, S., and Van Beusekom, J.: Biogenic silica dissolution in the oceans: Reconciling experimental and fieldbased dissolution rates, 4, American Geophysical Union, Washington, DC, Etats-Unis, 2002.

Varela, D. E., Pride, C. J., and Brzezinski, M. A.: Biological fractionation of silicon isotopes in Southern Ocean surface waters, Global Biogeochem. Cy., 18, GB1047, doi:10.1029/2003gb002140, 2004.

Ziegler, K., Chadwick, O. A., Brzezinski, M. A., and Kelly, E. F.: Natural variations of $\delta^{30} \mathrm{Si}$ ratios during progressive basalt weathering, Hawaiian Islands, Geochim. Cosmochim. Acta., 69, 4597-4610, 2005. 


\section{Appendix}

Table A1. Data for water samples from ANTXXIII/9.

\begin{tabular}{|c|c|c|c|c|c|c|c|}
\hline Station & Date & Latitude & Longitude & $\begin{array}{l}\text { Depth } \\
(\mathrm{m})\end{array}$ & $\begin{array}{l}{[\mathrm{DSi}]} \\
(\mu \mathrm{M})\end{array}$ & $\begin{array}{l}\delta^{30} \mathrm{Si} \pm \sigma \\
(\% \circ)\end{array}$ & Location \\
\hline CTD1 & $02 / 11 / 07$ & $69^{\circ} 24.03^{\prime} \mathrm{S}$ & $7^{\circ} 0.12^{\prime} \mathrm{W}$ & 20 & 57 & $1.63 \pm 0.06$ & \multirow{14}{*}{ Weddell Gyre } \\
\hline CTD1 & $02 / 11 / 07$ & $69^{\circ} 24.03^{\prime} \mathrm{S}$ & $7^{\circ} 0.12^{\prime} \mathrm{W}$ & 40 & 60.4 & $1.65 \pm 0.10$ & \\
\hline CTD1 & $02 / 11 / 07$ & $69^{\circ} 24.03^{\prime} \mathrm{S}$ & $7^{\circ} 0.12^{\prime} \mathrm{W}$ & 60 & 63.1 & $1.33 \pm 0.03$ & \\
\hline CTD1 & $02 / 11 / 07$ & $69^{\circ} 24.03^{\prime} \mathrm{S}$ & $7^{\circ} 0.12^{\prime} \mathrm{W}$ & 80 & 65.8 & $1.23 \pm 0.08$ & \\
\hline CTD1 & $02 / 11 / 07$ & $69^{\circ} 24.03^{\prime} \mathrm{S}$ & $7^{\circ} 0.12^{\prime} \mathrm{W}$ & 200 & 77.8 & $1.21 \pm 0.07$ & \\
\hline CTD1 & $02 / 11 / 07$ & $69^{\circ} 24.03^{\prime} \mathrm{S}$ & $7^{\circ} 0.12^{\prime} \mathrm{W}$ & 300 & 83.9 & $1.33 \pm 0.06$ & \\
\hline CTD1 & $02 / 11 / 07$ & $69^{\circ} 24.03^{\prime} \mathrm{S}$ & $7^{\circ} 0.12^{\prime} \mathrm{W}$ & 500 & 93.4 & $0.71 \pm 0.05$ & \\
\hline CTD1 & $02 / 11 / 07$ & $69^{\circ} 24.03^{\prime} \mathrm{S}$ & $7^{\circ} 0.12^{\prime} \mathrm{W}$ & 750 & 102.3 & $1.26 \pm 0.08$ & \\
\hline CTD1 & $02 / 11 / 07$ & $69^{\circ} 24.03^{\prime} \mathrm{S}$ & $7^{\circ} 0.12^{\prime} \mathrm{W}$ & 1000 & 106.5 & $1.17 \pm 0.03$ & \\
\hline CTD1 & $02 / 11 / 07$ & $69^{\circ} 24.03^{\prime} \mathrm{S}$ & $7^{\circ} 0.12^{\prime} \mathrm{W}$ & 1250 & 116.7 & $1.01 \pm 0.10$ & \\
\hline CTD1 & $02 / 11 / 07$ & $69^{\circ} 24.03^{\prime} \mathrm{S}$ & $7^{\circ} 0.12^{\prime} \mathrm{W}$ & 1500 & 114.4 & $1.18 \pm 0.04$ & \\
\hline CTD1 & $02 / 11 / 07$ & $69^{\circ} 24.03^{\prime} \mathrm{S}$ & $7^{\circ} 0.12^{\prime} \mathrm{W}$ & 1750 & 115.7 & $0.99 \pm 0.07$ & \\
\hline CTD1 & $02 / 11 / 07$ & $69^{\circ} 24.03^{\prime} \mathrm{S}$ & $7^{\circ} 0.12^{\prime} \mathrm{W}$ & 2000 & 117.2 & $1.08 \pm 0.06$ & \\
\hline CTD1 & $02 / 11 / 07$ & $69^{\circ} 24.03^{\prime} \mathrm{S}$ & $7^{\circ} 0.12^{\prime} \mathrm{W}$ & 2250 & 119.9 & $1.30 \pm 0.01$ & \\
\hline CTD4 & $02 / 24 / 07$ & $68^{\circ} 43.34^{\prime} \mathrm{S}$ & $70^{\circ} 40.66^{\prime} \mathrm{E}$ & 20 & 36.8 & $2.13 \pm 0.02$ & \multirow{6}{*}{ Prydz Bay } \\
\hline CTD4 & $02 / 24 / 07$ & $68^{\circ} 43.34^{\prime} \mathrm{S}$ & $70^{\circ} 40.66^{\prime} \mathrm{E}$ & 40 & 48.8 & $1.71 \pm 0.02$ & \\
\hline CTD4 & $02 / 24 / 07$ & $68^{\circ} 43.34^{\prime} \mathrm{S}$ & $70^{\circ} 40.66^{\prime} \mathrm{E}$ & 60 & 52.8 & - & \\
\hline CTD4 & $02 / 24 / 07$ & $68^{\circ} 43.34^{\prime} \mathrm{S}$ & $70^{\circ} 40.66^{\prime} \mathrm{E}$ & 80 & 55.3 & - & \\
\hline CTD4 & $02 / 24 / 07$ & $68^{\circ} 43.34^{\prime} \mathrm{S}$ & $70^{\circ} 40.66^{\prime} \mathrm{E}$ & 200 & 57.7 & $1.60 \pm 0.02$ & \\
\hline CTD4 & $02 / 24 / 07$ & $68^{\circ} 43.34^{\prime} \mathrm{S}$ & $70^{\circ} 40.66^{\prime} \mathrm{E}$ & 500 & 58.7 & - & \\
\hline CTD6 & $03 / 21 / 07$ & $65^{\circ} 20.98^{\prime} S$ & $82^{\circ} 39.48^{\prime} \mathrm{E}$ & 20 & 53.5 & $1.44 \pm 0.04$ & \multirow{6}{*}{ Prydz Bay } \\
\hline CTD6 & $03 / 21 / 07$ & $65^{\circ} 20.98^{\prime} \mathrm{S}$ & $82^{\circ} 39.48^{\prime} \mathrm{E}$ & 40 & 50.2 & $1.42 \pm 0.04$ & \\
\hline CTD6 & $03 / 21 / 07$ & $65^{\circ} 20.98^{\prime} \mathrm{S}$ & $82^{\circ} 39.48^{\prime} \mathrm{E}$ & 60 & 54 & $1.18 \pm 0.06$ & \\
\hline CTD6 & $03 / 21 / 07$ & $65^{\circ} 20.98^{\prime} S$ & $82^{\circ} 39.48^{\prime} \mathrm{E}$ & 80 & 57.3 & $1.13 \pm 0.05$ & \\
\hline CTD6 & $03 / 21 / 07$ & $65^{\circ} 20.98^{\prime} \mathrm{S}$ & $82^{\circ} 39.48^{\prime} \mathrm{E}$ & 200 & 64.9 & $1.59 \pm 0.03$ & \\
\hline CTD6 & $03 / 21 / 07$ & $65^{\circ} 20.98^{\prime} S$ & $82^{\circ} 39.48^{\prime} \mathrm{E}$ & 500 & 88.1 & $1.35 \pm 0.07$ & \\
\hline CTD5 & $03 / 02 / 07$ & $60^{\circ} 56.97^{\prime} \mathrm{S}$ & $72^{\circ} 43.30^{\prime} \mathrm{E}$ & 30 & 20.2 & & \multirow{12}{*}{$\begin{array}{l}\text { Antarctic } \\
\text { Circumpolar } \\
\text { Current }\end{array}$} \\
\hline CTD5 & $03 / 02 / 07$ & $60^{\circ} 56.97^{\prime} \mathrm{S}$ & $72^{\circ} 43.30^{\prime} \mathrm{E}$ & 40 & 21.6 & $2.21 \pm 0.08$ & \\
\hline CTD5 & $03 / 02 / 07$ & $60^{\circ} 56.97^{\prime} \mathrm{S}$ & $72^{\circ} 43.30^{\prime} \mathrm{E}$ & 60 & 37.5 & - & \\
\hline CTD5 & $03 / 02 / 07$ & $60^{\circ} 56.97^{\prime} \mathrm{S}$ & $72^{\circ} 43.30^{\prime} \mathrm{E}$ & 80 & 39.6 & $1.62 \pm 0.06$ & \\
\hline CTD5 & $03 / 02 / 07$ & $60^{\circ} 56.97^{\prime} \mathrm{S}$ & $72^{\circ} 43.30^{\prime} \mathrm{E}$ & 200 & 72.9 & $1.25 \pm 0.03$ & \\
\hline CTD5 & $03 / 02 / 07$ & $60^{\circ} 56.97^{\prime} \mathrm{S}$ & $72^{\circ} 43.30^{\prime} \mathrm{E}$ & 500 & 81.4 & $1.20 \pm 0.04$ & \\
\hline CTD5 & 03/02/07 & $60^{\circ} 56.97^{\prime} \mathrm{S}$ & $72^{\circ} 43.30^{\prime} \mathrm{E}$ & 1000 & 82 & $1.07 \pm 0.03$ & \\
\hline CTD5 & 03/02/07 & $60^{\circ} 56.97^{\prime} \mathrm{S}$ & $72^{\circ} 43.30^{\prime} \mathrm{E}$ & 1500 & 97.9 & $0.96 \pm 0.05$ & \\
\hline CTD5 & $03 / 02 / 07$ & $60^{\circ} 56.97^{\prime} \mathrm{S}$ & $72^{\circ} 43.30^{\prime} \mathrm{E}$ & 2000 & 106.9 & $1.12 \pm 0.06$ & \\
\hline CTD5 & $03 / 02 / 07$ & $60^{\circ} 56.97^{\prime} \mathrm{S}$ & $72^{\circ} 43.30^{\prime} \mathrm{E}$ & 2500 & 120.7 & $0.92 \pm 0.07$ & \\
\hline CTD5 & $03 / 02 / 07$ & $60^{\circ} 56.97^{\prime} \mathrm{S}$ & $72^{\circ} 43.30^{\prime} \mathrm{E}$ & 3000 & 121.2 & $1.04 \pm 0.05$ & \\
\hline CTD5 & 03/02/07 & $60^{\circ} 56.97^{\prime} \mathrm{S}$ & $72^{\circ} 43.30^{\prime} \mathrm{E}$ & 3500 & 122.1 & $1.10 \pm 0.05$ & \\
\hline CTD5 & $03 / 02 / 07$ & $60^{\circ} 56.97^{\prime} \mathrm{S}$ & $72^{\circ} 43.30^{\prime} \mathrm{E}$ & 4000 & 125.4 & 0.09 & \multirow{13}{*}{$\begin{array}{l}\text { South of } \\
\text { Antarctic } \\
\text { Circumpolar } \\
\text { Current }\end{array}$} \\
\hline CTD7 & $03 / 24 / 07$ & $59^{\circ} 37.25^{\prime} \mathrm{S}$ & $85^{\circ} 40.52^{\prime} \mathrm{E}$ & 20 & 28.1 & $1.90 \pm 0.15$ & \\
\hline CTD7 & $03 / 24 / 07$ & $59^{\circ} 37.25^{\prime} \mathrm{S}$ & $85^{\circ} 40.52^{\prime} \mathrm{E}$ & 40 & 41.5 & $2.21 \pm 0.09$ & \\
\hline CTD7 & $03 / 24 / 07$ & $59^{\circ} 37.25^{\prime} \mathrm{S}$ & $85^{\circ} 40.52^{\prime} \mathrm{E}$ & 60 & 55.3 & $1.32 \pm 0.06$ & \\
\hline CTD7 & $03 / 24 / 07$ & $59^{\circ} 37.25^{\prime} \mathrm{S}$ & $85^{\circ} 40.52^{\prime} \mathrm{E}$ & 80 & 60.9 & $1.53 \pm 0.07$ & \\
\hline CTD7 & $03 / 24 / 07$ & $59^{\circ} 37.25^{\prime} \mathrm{S}$ & $85^{\circ} 40.52^{\prime} \mathrm{E}$ & 200 & 76.2 & $1.25 \pm 0.05$ & \\
\hline CTD7 & $03 / 24 / 07$ & $59^{\circ} 37.25^{\prime} \mathrm{S}$ & $85^{\circ} 40.52^{\prime} \mathrm{E}$ & 500 & 88.1 & $1.44 \pm 0.02$ & \\
\hline CTD7 & $03 / 24 / 07$ & $59^{\circ} 37.25^{\prime} \mathrm{S}$ & $85^{\circ} 40.52^{\prime} \mathrm{E}$ & 1000 & 94.2 & - & \\
\hline CTD7 & $03 / 24 / 07$ & $59^{\circ} 37.25^{\prime} \mathrm{S}$ & $85^{\circ} 40.52^{\prime} \mathrm{E}$ & 1500 & 117.3 & - & \\
\hline CTD7 & $03 / 24 / 07$ & $59^{\circ} 37.25^{\prime} \mathrm{S}$ & $85^{\circ} 40.52^{\prime} \mathrm{E}$ & 2000 & 120.8 & - & \\
\hline CTD7 & $03 / 24 / 07$ & $59^{\circ} 37.25^{\prime} \mathrm{S}$ & $85^{\circ} 40.52^{\prime} \mathrm{E}$ & 2500 & 118.5 & - & \\
\hline CTD7 & $03 / 24 / 07$ & $59^{\circ} 37.25^{\prime} \mathrm{S}$ & $85^{\circ} 40.52^{\prime} \mathrm{E}$ & 3000 & 118.1 & - & \\
\hline CTD7 & $03 / 24 / 07$ & $59^{\circ} 37.25^{\prime} \mathrm{S}$ & $85^{\circ} 40.52^{\prime} \mathrm{E}$ & 3500 & 119.6 & - & \\
\hline CTD8 & $03 / 26 / 07$ & $55^{\circ} 0.30^{\prime} \mathrm{S}$ & $73^{\circ} 19.98^{\prime} \mathrm{E}$ & 20 & 11.6 & & \multirow{6}{*}{$\begin{array}{l}\text { Kerguelen } \\
\text { Plateau }\end{array}$} \\
\hline CTD8 & $03 / 26 / 07$ & $55^{\circ} 0.30^{\prime} \mathrm{S}$ & $73^{\circ} 19.98^{\prime} \mathrm{E}$ & 40 & 11.7 & $2.20 \pm 0.07$ & \\
\hline CTD8 & $03 / 26 / 07$ & $55^{\circ} 0.30^{\prime} \mathrm{S}$ & $73^{\circ} 19.98^{\prime} \mathrm{E}$ & 60 & 11.4 & $1.99 \pm 0.03$ & \\
\hline CTD8 & $03 / 26 / 07$ & $55^{\circ} 0.30^{\prime} \mathrm{S}$ & $73^{\circ} 19.98^{\prime} \mathrm{E}$ & 80 & 31.5 & $0.94 \pm 0.02$ & \\
\hline CTD8 & $03 / 26 / 07$ & $55^{\circ} 0.30^{\prime} \mathrm{S}$ & $73^{\circ} 19.98^{\prime} \mathrm{E}$ & 500 & 66.8 & $1.40 \pm 0.04$ & \\
\hline CTD8 & $03 / 26 / 07$ & $55^{\circ} 0.30^{\prime} \mathrm{S}$ & $73^{\circ} 19.98^{\prime} \mathrm{E}$ & 1500 & 82.4 & $1.57 \pm 0.02$ & \\
\hline
\end{tabular}

